\title{
Cav1.4 dysfunction and congenital stationary night blindness type 2
}

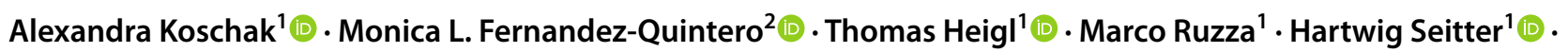 \\ Lucia Zanetti ${ }^{1}$
}

Received: 4 January 2021 / Revised: 14 April 2021 / Accepted: 18 April 2021 / Published online: 1 July 2021

(c) The Author(s) 2021

\begin{abstract}
Cav1.4 L-type $\mathrm{Ca}^{2+}$ channels are predominantly expressed in retinal neurons, particularly at the photoreceptor terminals where they mediate sustained $\mathrm{Ca}^{2+}$ entry needed for continuous neurotransmitter release at their ribbon synapses. Cav1.4 channel gating properties are controlled by accessory subunits, associated regulatory proteins, and also alternative splicing. In humans, mutations in the CACNAIF gene encoding for Cav1.4 channels are associated with X-linked retinal disorders such as congenital stationary night blindness type 2. Mutations in the Cav1.4 protein result in a spectrum of altered functional channel activity. Several mouse models broadened our understanding of the role of Cav1.4 channels not only as $\mathrm{Ca}^{2+}$ source at retinal synapses but also as synaptic organizers. In this review, we highlight different structural and functional phenotypes of Cav1.4 mutations that might also occur in patients with congenital stationary night blindness type 2 . A further important yet mostly neglected aspect that we discuss is the influence of alternative splicing on channel dysfunction. We conclude that currently available functional phenotyping strategies should be refined and summarize potential specific therapeutic options for patients carrying Cav1.4 mutations. Importantly, the development of new therapeutic approaches will permit a deeper understanding of not only the disease pathophysiology but also the physiological function of Cav1.4 channels in the retina.
\end{abstract}

Keywords Calcium channel $\cdot$ Cav1.4 Channelopathy $\cdot$ Channel modulation $\cdot$ Retinal disease $\cdot$ Congenital stationary night blindness type 2

\section{Introduction}

Cav1.4 L-type $\mathrm{Ca}^{2+}$ channels (LTCC, Cav1 family) are predominantly expressed in retinal neurons, particularly at the photoreceptor terminals. The LTCC identity in bipolar cells specifically is controversial but the presence of all Cav1 subunits has been reported including Cav1.4 [14, 80, 117]. Cav1.4 expression has further been reported in dorsal root

This article is part of the special issue on Function and Dysfunction in Vertebrate Photoreceptor Cells in Pflügers Archiv-European Journal of Physiology

Alexandra Koschak alexandra.koschak@uibk.ac.at

1 Institute of Pharmacy, Pharmacology and Toxicology, Center for Chemistry and Biomedicine, University of Innsbruck, Innrain 80-82/III, 6020 Innsbruck, Austria

2 Institute of General, Inorganic and Theoretical Chemistry, Center for Chemistry and Biomedicine, University of Innsbruck, Innrain 80-82/III, 6020 Innsbruck, Austria ganglia neurons, mast cells, and T-lymphocytes (for review, see [70]).

The gating properties of Cav1.4 channels $[11,53,64]$ are perfectly suited to mediate sustained $\mathrm{Ca}^{2+}$ entry needed for continuous release of neurotransmitters at photoreceptor ribbon synapses in the dark [84, 102]. Upon light absorption in the photoreceptor outer segments, the closure of cGMP-gated cation channels hyperpolarizes the photoreceptors cells (below $-55 \mathrm{mV}$ [110]). In the dark, photoreceptor membrane potential depolarizes $(-36$ to $-40 \mathrm{mV}$ ) and thereby enhances tonic neurotransmitter (glutamate) release [24]. For such tonic release, only a few channels that activate rapidly at relatively negative voltages $(<-40 \mathrm{mV}$, $[10,34,101])$ and inactivate slowly are needed [10]. Indeed, heterologously expressed Cav1.4 LTCCs show fast activation and allow $\mathrm{Ca}^{2+}$ influx at membrane potentials negative to $-40 \mathrm{mV}$. In addition, Cav1.4 currents show slow voltage-dependent inactivation (VDI) with complete absence of $\mathrm{Ca}^{2+}$-dependent inactivation (CDI) [53, 84]. Of note, near physiological temperatures, inactivation kinetics were accelerated but the window current that may be seen as a 
"window" of voltages where the activation and steady-state inactivation curves overlap is still preserved [74]. Cav1.4 channels lack CDI due to active suppression by an inhibitory domain in their C-terminus [84, 102]. This phenomenon is referred to as C-terminal modulation (CTM). In Cav1.4 (and also Cav1.3) channels, the modulation is attributable to an interaction of a proximal (PCRD) and a distal (DCRD) C-terminal regulatory domain (Fig. 1), which are putative $\alpha$-helices $[84,85]$. Due to the competition of the distal C-terminus with calmodulin (CaM) binding [57], CDI is absent (or weaker in Cav1.3) [20, 84, 85]. The CTM not only determines CDI but also affects the channel's activation gating properties and the open probability [16, 44, 45, 85]. Interestingly, CTM elimination in Cav1.3 channels in hair cells and chromaffin cells affected CDI but not the channels' activation threshold [81].

$\mathrm{CaM}$ is important for Cav1.4 function because it increases current density and slows down VDI [32] in addition to its role as a specific channel-bound $\mathrm{Ca}^{2+}$ sensor that is tethered to upstream regions of the $\mathrm{C}$-terminal tail such as the helical IQ domain adjacent to the so-called EF-hand motif (Fig. 1). $\mathrm{Ca}^{2+}$-binding protein 4 (CaBP4) competes with $\mathrm{CaM}$ for the IQ motif of the channel by disrupting interaction between IQ and the distal C-terminus [72]. Moreover, CaBP4 increased channel availability in a heterologous expression system, by increasing the channel's window current [82]. Auxiliary subunits $\alpha 2 \delta$ and $\beta$ have been shown to modulate electrophysiological properties as well as increase the number of voltage-gated $\mathrm{Ca}^{2+}$ channels on the membrane (see review $[19,27])$. The $\beta$ subunit interacts with the alpha-interaction domain (AID) of the channel, while $\alpha 2 \delta$ subunits mainly interact with an extracellular loop in domain I (Fig. 1). More specifically, the $\beta 2$ variants $\beta 2 \mathrm{a}$ and $\beta 2 \mathrm{X} 13$, which have been reported to assemble with Cav1.4 in photoreceptors, differentially modulated Cav1.4 properties but both support slow inactivation [56] and are necessary for forward trafficking. Among $\alpha 2 \delta$ subunits, $\alpha 2 \delta 4$ is part of the Cav1.4 channel complex in photoreceptors [56] and supports Cav1.4 functional expression not only in tsa-201 cells [7] but also in photoreceptor terminals [49] likely by enhancing the stability of Cav1.4 channels by suppressing their turnover.

The important role of Cav1.4 in the retina is evident from mutations in the CACNAIF gene encoding Cav1.4 LTCCs that cause retinal diseases in humans (OMIM $300,071,300,476,300,600)$ such as congenital stationary night blindness type 2 (CSNB2, OMIM 300,071; Table 1). Mutations in the $\alpha 2 \delta 4$ subunit (CACNA2D4 gene [115]) and CaBP4 [122]—both are proteins that interact with Cav1.4 (Fig. 1) - are also associated with CSNB2 [124]. CSNB2 patients show variable levels of night blindness together with

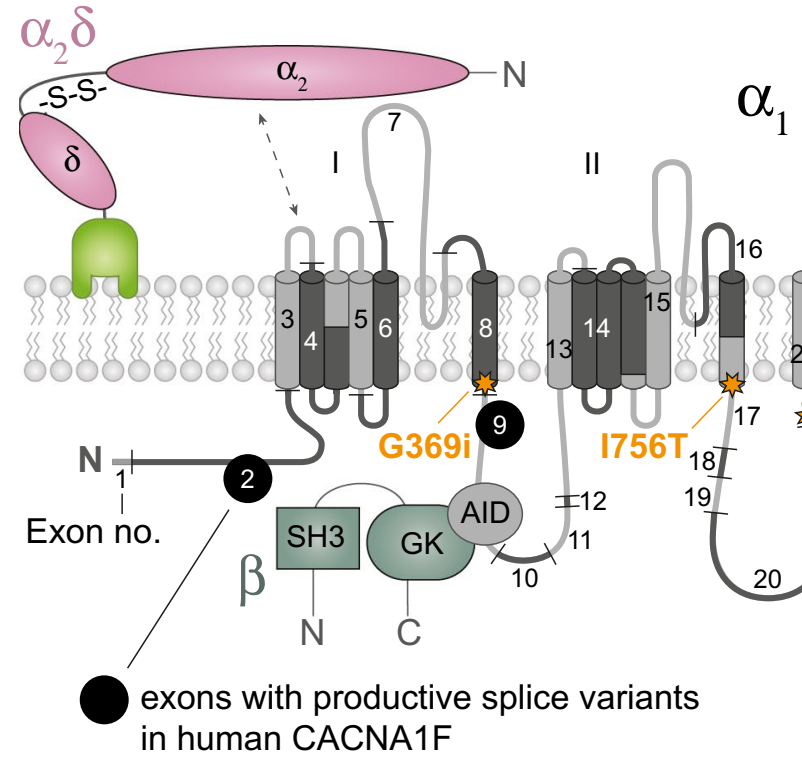

Fig. 1 Protein topology of human Cav1.4 with coding exons, alternatively spliced exons (see Table 2) and selected mutations annotated (according to human reference sequence NP_005174) together with an intracellular $\beta$ and an extracellular $\alpha 2 \delta$ and potential interaction sites with calmodulin $(\mathrm{CaM})$ and $\mathrm{Ca}^{2+}$ binding proteins $(\mathrm{CaBP})$.
Abbreviations: VDI, voltage-dependence of inactivation, CDI, $\mathrm{Ca}^{2+}$-dependence of inactivation; $\mathrm{P}_{\mathrm{o}}$, open probability, AID, alphainteraction domain; EF, EF-hand motif; other abbreviations, see main text 
Table 1 Disease-causing mutations in human Cav1.4 $\alpha 1$-subunits. Different types of mutations have been reported: $M$, missense; $T$, truncation; Del, deletion; Ins, insertion; Dup, duplication. Numbering according to reference sequence AJ006216. Note, the position 745 of Ile to Thr mutation refers to the original report [35]; the reference sequence contains a short exon 9

\begin{tabular}{|c|c|c|c|c|c|}
\hline exon & mutation type & nucleotide & protein & channel domain & reference \\
\hline 2 & $\mathrm{~T}$ & $148 \mathrm{C}>\mathrm{T}$ & Arg50stop & $N$-terminus & [17] \\
\hline 2 & Del/Ins/Dup & 151_155delAGAAA & Arg51Profs*65 & N-terminus & {$[114]$} \\
\hline 2 & $M$ & $208 C>T$ & Arg70W & N-terminus & {$[15]$} \\
\hline 2 & M & $220 T>C$ & Cys74Arg & N-terminus & {$[114]$} \\
\hline 2 & $\mathrm{~T}$ & $244 C>T$ & Arg82stop & N-terminus & {$[17,114,122,124]$} \\
\hline 2 & M & $245 G>A$ & Arg82Gln & N-terminus & {$[124]$} \\
\hline 2 & Del/Ins/Dup & 244insG & Arg83Thrfs*35 & N-terminus & {$[15]$} \\
\hline 2 & $\mathrm{~T}$ & $272 G>A$ & Trp9stop & $N$-terminus to ISI & {$[41]$} \\
\hline 3 & Del/Ins/Dup & 281dup & Asp95Argfs*23 & IS1 & {$[15]$} \\
\hline 3 & $M$ & $299 T>G$ & Leu100Pro & $\mid S 1$ & {$[124]$} \\
\hline 3 & Del/Ins/Dup & $371 d u p$ & Asn124Lysfs*175 & IS1-IS2 linker & {$[124]$} \\
\hline 4 & $\mathrm{~T}$ & $396 C>A$ & Tyr132stop & $1 S 2$ & {$[124]$} \\
\hline 4 & Del/Ins/Dup & $413 \mathrm{del}$ & Phe138Serfs*65 & 152 & [15] \\
\hline 4 & $M$ & $448 G>C$ & Gly150Arg & 152 & [106] \\
\hline 4 & Del/Ins/Dup & $\begin{array}{c}\text { 466_469delAGCGi } \\
\text { ns34nt }\end{array}$ & Ser156_Ala157delins12 & IS2-IS3 linker & {$[17,68,67]$} \\
\hline 4 & M & $469 G>C$ & Ala157Pro & IS2-IS3 linker & {$[15]$} \\
\hline 4 & Del/Ins/Dup & $\begin{array}{c}\text { c621_1392delinsC } \\
\text { TCATTG }\end{array}$ & Phe208_Leu1977delins20 & $1 S 4$ & {$[15]$} \\
\hline 5 & M & $647 \mathrm{~T}>\mathrm{G}$ & Leu216Arg & IS4 & {$[124]$} \\
\hline 6 & M & $685 T>C$ & Ser229Pro & linker IS4-IS5 & {$[114]$} \\
\hline 6 & M & $764 G>A$ & Gly255Glu & $1 S 5$ & {$[65]$} \\
\hline 6 & M & $781 G>A$ & Gly261Arg & IS5-IS6 linker & {$[114]$} \\
\hline 6 & Del/Ins/Dup & $\begin{array}{c}\text { 796_797delinsGAA } \\
\text { СTT }\end{array}$ & hr266Glufs*34 & IS5-IS6 linker & {$[124]$} \\
\hline 6 & Del/Ins/Dup & 808del & Leu270Trfs*25 & IS5-IS6 linker & {$[15]$} \\
\hline 7 & $\mathrm{~T}$ & $832 \mathrm{G}>\mathrm{T}$ & Glu278stop & IS5-IS6 linker & {$[126]$} \\
\hline 7 & Del/Ins/Dup & 903_904insG & Arg302Alafs*13 & IS5-IS6 linker & {$[68]$} \\
\hline 7 & M & $926 G>A$ & Gly309Asp & IS5-IS6Linker & {$[124]$} \\
\hline 7 & Del/Ins/Dup & 935 delA & Asp312ThrfsX10 & IS5-IS6Linker & {$[122]$} \\
\hline 7 & Del/Ins/Dup & 943_945delAAC & Asn315del & IS5-IS6Linker & {$[124]$} \\
\hline 7 & Del/Ins/Dup & 945_947delCTT & Phe318del & IS5-IS6Linker & {$[17]$} \\
\hline 7 & $T$ & $973 C>T$ & Gln325stop & IS5-IS6Linker & {$[4]$} \\
\hline 7 & Del/Ins/Dup & 985_986insC & Met329Thrfs*18 & IS5-IS6Linker & {$[124]$} \\
\hline 7 & Del/Ins/Dup & $\begin{array}{c}\text { 1004_1009delTGC } \\
\text { TCT }\end{array}$ & Val335_Tyr337delinsAsp & IS5-IS6Linker & {$[124]$} \\
\hline
\end{tabular}

myopia, nystagmus, strabismus, and low visual acuity [15]. In particular, patients that carry $C A C N A I F$ mutations may present with only few or even no night vision problems [66,
124]. Visual fields in CSNB2 patients are normal but daylight vision, color vision, and visual acuity can be affected [15]. More than $50 \%$ of the patients suffer from photophobia 
Table 1 (continued)

\begin{tabular}{|c|c|c|c|c|c|}
\hline 8 & T & $1046 G>A$ & Trp349stop & IS5-IS6Linker to S6 & {$[83,124]$} \\
\hline 8 & $M$ & $1075 G>A$ & Gly359Arg & 156 & [83] \\
\hline 8 & $M$ & $1106 \mathrm{G}>\mathrm{A}$ & Gly369Asp & IS6 & {$[90,17,114,124]$} \\
\hline 8 & Del/Ins/Dup & $1118 p$ & Glu374Valfs*96 & I-II loop & [15] \\
\hline 9 & T & 207_5472 & Arg379stop & I-II loop & [15] \\
\hline 9 & Del/Ins/Dup & 1213delC & Leu405Trpfs*28 & $|-| \mid l o o p$ & {$[12,126,124]$} \\
\hline 10 & $\mathrm{~T}$ & $1282 C>T$ & Gln428stop & |-II loop & [114] \\
\hline 9 & M & $1301 C>T$ & Ala434Val & I-II loop & {$[41]$} \\
\hline 11 & M & $1464 G>T$ & Glu488Asp & I-II loop & [43] \\
\hline 11 & T & $1485 \mathrm{~T}>\mathrm{A}$ & Cys495stop & $|-| \mid l o o p$ & [41] \\
\hline 13 & T & $1504 C>T$ & Arg502stop & |-II loop & [124] \\
\hline 13 & M & $1523 G>A$ & Arg508Gln & |-II loop & {$[90,122]$} \\
\hline 13 & $M$ & $1555 C>T$ & Arg519Trp & I-II loop & [125] \\
\hline 14 & $\mathrm{~T}$ & $1761 C>A$ & Cys587stop & IIS3 & [124] \\
\hline 14 & $M$ & $1807 G>C$ & Gly603Arg & IIS3 & [100] \\
\hline 14 & $T$ & $1816 C>T$ & Cys606stop & IIS3-S4 linker & [124] \\
\hline 14 & $\mathrm{~T}$ & $1840 \mathrm{C}>\mathrm{T}$ & Arg614stop & IIS3-S4 linker & {$[17,114,124]$} \\
\hline 14 & $M$ & $1870 G>A$ & Val624lle & IIS4 & {$[106]$} \\
\hline 15 & M & $1988 G>A$ & Gly663Asp & 1155 & [17] \\
\hline 15 & $\mathrm{~T}$ & $2038 C>T$ & Arg680stop & IIS5-S6 linker & {$[123,122,124]$} \\
\hline 15 & $\mathrm{~T}$ & $2071 C>T$ & Arg691stop & IIS5-IIS6 linker & [15] \\
\hline 16 & $M$ & 2090T>C & Leu697Pro & IIS-IIS6 linker & {$[65]$} \\
\hline 16 & $M$ & $2204 A>C$ & Asn735Thr & 1156 & [122] \\
\hline 17 & Del/Ins/Dup & 2213del & Leu738Argfs*2 & 1156 & [15] \\
\hline 17 & $M$ & $2225 T>G$ & Phe742Cys & 1156 & [114] \\
\hline 17 & M & $2234 T>C$ & $\begin{array}{l}\text { Ile745Thr (1756T in } \\
\text { Figures) }\end{array}$ & 1156 & {$[40]$} \\
\hline 17 & Del/Ins/Dup & 2246delT & Leu749Argfs*2 & 1156 & [15] \\
\hline 17 & T & $2314 A>T$ & Lys772* & II-III linker & {$[41]$} \\
\hline 19 & M & $2390 A>T$ & Glu797Val & II-III linker & {$[41]$} \\
\hline 21 & M & $2546 \mathrm{~T}>\mathrm{C}$ & $\begin{array}{l}\text { Leu849Pro (L860P in } \\
\text { Figures) }\end{array}$ & II-III linker to IIIS1 & [114] \\
\hline 21 & Del/Ins/Dup & 2590_2591del & Asn864Serfs*16 & IIIS1 & {$[15]$} \\
\hline 21 & T & $2650 C>T$ & Arg884stop & IIIS1-S2 linker & {$[12,17,124]$} \\
\hline 23 & M & $2747 G>C$ & Gly916Ala & IIIS2-IIIS3 linker & {$[15]$} \\
\hline 23 & $M$ & $2750 C>A$ & Ala917Asp & IIIS2-IIIS3 linker & {$[17]$} \\
\hline
\end{tabular}


Table 1 (continued)

\begin{tabular}{|c|c|c|c|c|c|}
\hline 23 & M & $2779 A>G$ & Ser927Gly & IIIS2-IIIS3 linker & [124] \\
\hline 23 & M & $2780 G>C$ & Gly927Ala & IIIS2-IIIS3 linker & [15] \\
\hline 23 & M & $2789 A>C$ & Asn930Thr & IIIS3 & [124] \\
\hline 23 & M & $2797 \mathrm{G}>\mathrm{T}$ & Asp933Tyr & IIIS3 & {$[122]$} \\
\hline 23 & Del/Ins/Dup & $\begin{array}{c}\text { 2796_2797delinsC } \\
\text { T }\end{array}$ & $\begin{array}{c}\text { Leu932_Asp933 } \\
\text { delinsPheTyr }\end{array}$ & IIIS3 & [124] \\
\hline 23 & Del/Ins/Dup & 2821dupC & Leu941Pfs*115 & IIIS3 & {$[65]$} \\
\hline 23 & Del/Ins/Dup & 2844delC & Ser949Valfs*17 & IIIS3 & [41] \\
\hline 24 & $\mathrm{~T}$ & $2872 C>T$ & Arg958stop & IIIS4 & {$[90,122,124]$} \\
\hline 24 & $\mathrm{~T}$ & $2881 C>T$ & Arg961stop & IIIS4 & [126] \\
\hline 24 & $\mathrm{~T}$ & $2899 C>T$ & Arg967stop & IIIS4 & {$[90,67,122,124]$} \\
\hline 24 & M & $2923 C>G$ & Arg975Gly & IIIS4 & {$[41]$} \\
\hline 24 & $\mathrm{~T}$ & $2932 C>T$ & Arg978stop & IIIS4 & [43] \\
\hline 25 & Del/Ins/Dup & 2973_2975delCAT & |le992del & IIIS5 & {$[17]$} \\
\hline 25 & M & $3019 G>A$ & Gly1007Arg & IIIS5 & {$[114,122,124]$} \\
\hline 26 & Del/Ins/Dup & $\begin{array}{c}\text { 3088_3089p } \\
\text { 2delAAGT }\end{array}$ & Lys1030Glyfs* & IIIS5-IIIS6 linker & [124] \\
\hline 27 & Del/Ins/Dup & 3118delG & Asp1040Thrfs*26 & IIIS5-IIIS6 linker & {$[17]$} \\
\hline 27 & Del/Ins/Dup & 3133_3134insC & Leu1045Profs*11 & IIIS5-IIIS6 linker & {$[12,90,17,124]$} \\
\hline 27 & M & $3145 C>T$ & Arg1049Trp & IIIS5-IIIS6 linker & {$[90]$} \\
\hline 27 & M & $3203 T>C$ & Leu1068Pro & IIIS5-IIIS6 linker & {$[114]$} \\
\hline 27 & Del/Ins/Dup & 3212_3213delAT & Asn1071Serfs*15 & IIIS5-IIIS6 linker & {$[41]$} \\
\hline & $\mathrm{T}$ & $3308 C>A$ & Ser1103stop & IIIS5-IIIS6 linker & {$[15]$} \\
\hline 28 & $\mathrm{~T}$ & $3341 C>T$ & Ser1114stop & IIIS6 & {$[15]$} \\
\hline & M & $3400 G>A$ & Glu1134Lys & III-IV linker & {$[122]$} \\
\hline 28 & $M$ & $3401 G>C$ & Gly1134Asp & III-IV linker & {$[1]$} \\
\hline 28 & $M$ & $3400 G>A$ & Glu1134Lys & III-IV linker & {$[122]$} \\
\hline 28 & Del/Ins/Dup & 3407delA & Glu1136Glyfs*41 & III-IV linker & {$[124]$} \\
\hline 29 & M & $3458 C>A$ & Ala1153Asp & III-IV linker & {$[124]$} \\
\hline 29 & Del/Ins/Dup & 3471_3472delGC & Gln1157HisX25 & III-IV linker & {$[122]$} \\
\hline 29 & Del/Ins/Dup & 3512delG & Arg1171Profs*17 & III-IV linker & [41] \\
\hline 30 & Del/Ins/Dup & 3638delC & Leu1214Serfs*42 & IVS2 & {$[12]$} \\
\hline
\end{tabular}


Table 1 (continued)

\begin{tabular}{|c|c|c|c|c|c|}
\hline 30 & Del/Ins/Dup & $\begin{array}{c}\text { 3658_3669delGGC } \\
\text { СТСTTCACT }\end{array}$ & 1220delGlyLeuPheThr & IVS2 & {$[12,114]$} \\
\hline 30 & M & $3662 T>G$ & Leu1221Arg & IVS2 & [124] \\
\hline 30 & M & $3666 \mathrm{G}>\mathrm{T}$ & Met1222lle & IVS2 & [41] \\
\hline 31 & M & $3761 \mathrm{G}>\mathrm{T}$ & Ser1254lle & IVS3 & [123] \\
\hline 33 & M & $3853 C>A$ & Arg1285Ser & IVS3 & [123] \\
\hline 33 & M & $3853 C>T$ & Arg1285Cys & IVS4 & [124] \\
\hline 33 & $\mathrm{~T}$ & $3862 C>T$ & Arg1288stop & IVS4 & {$[12,114,122]$} \\
\hline 33 & M & $3869 \mathrm{G}>\mathrm{T}$ & Arg1299Leu & IVS4 & [41] \\
\hline 33 & $\mathrm{~T}$ & $3895 C>T$ & R1299stop & IVS4 & [73] \\
\hline 35 & M & $4016 \mathrm{G}>\mathrm{T}$ & $\begin{array}{c}\text { Gly1339Val (G1350V in } \\
\text { Figures) }\end{array}$ & $\begin{array}{c}\text { IVS5 to IVS5-IVS6 } \\
\text { linker }\end{array}$ & [124] \\
\hline 35 & $\mathrm{~T}$ & $4042 C>T$ & Gln1348stop & IVS5-IVS6 linker & {$[90,114]$} \\
\hline 35 & $\mathrm{~T}$ & $4051 C>T$ & Arg1351stop & IVS5-IVS6 linker & {$[124]$} \\
\hline 35 & $M$ & $4091 T>A$ & Leu1364His & IVS5-IVS6 linker & {$[90,122]$} \\
\hline 36 & M & $4226 A>G$ & Tyr1409Cys & IVS6 & [124] \\
\hline 37 & $\mathrm{~T}$ & $4320>A$ & Trp1440stop & C-terminus & [12] \\
\hline 37 & M & $4364 \mathrm{G}>\mathrm{T}$ & Trp1455Leu & C-terminus & [124] \\
\hline 37 & M & $4396 \mathrm{~T}>\mathrm{C}$ & Trp1466Arg & C-terminus & [41] \\
\hline 38 & M & $4424 \mathrm{~T}>\mathrm{C}$ & Leu1475Pro & C-terminus & [122] \\
\hline 38 & Del/Ins/Dup & 4433del & Ile1478Thrfs*23 & C-terminus & {$[124]$} \\
\hline 38 & Del/Ins/Dup & 4438_4439delTT & Leu1480Glyfs*88 & C-terminus & {$[41]$} \\
\hline 38 & M & $4441 C>G$ & Pro1481Ala & C-terminus & {$[122,124]$} \\
\hline 38 & M & $4447 G>A$ & Gly1483Arg & C-terminus & {$[124]$} \\
\hline 38 & $M$ & $4462 \mathrm{~T}>\mathrm{C}$ & Cys1488Arg & C-terminus & {$[114]$} \\
\hline 38 & M & $4466 C>G$ & Pro1489Arg & C-terminus & {$[114,83]$} \\
\hline 38 & M & $4490 \mathrm{~T}>\mathrm{C}$ & Leu1497Pro & C-terminus & {$[114,122]$} \\
\hline 39 & Del/Ins/Dup & $\begin{array}{c}4547 \_4549 \text { delinsC } \\
\text { C }\end{array}$ & Leu1516Profs $* 9$ & C-terminus & {$[65]$} \\
\hline 39 & Del/Ins/Dup & 4551delT & Phe1517Leufs*8 & C-terminus & {$[46]$} \\
\hline 39 & M & $4579 C>T$ & Leu1527Phe & C-terminus & {$[41]$} \\
\hline 39 & M & $4594 C>T$ & Arg1532Trp & C-terminus & [41] \\
\hline 41 & $\mathrm{~T}$ & $4735 C>T$ & Gln1579stop & C-terminus & [124] \\
\hline
\end{tabular}


Table 1 (continued)

\begin{tabular}{|c|c|c|c|c|c|}
\hline 41 & $\mathrm{~T}$ & 4771A>T & Lys1591stop & C-terminus & [90] \\
41 & Del/Ins/Dup & 4812delC & Ala1605Profs*144 & C-terminus & C-terminus \\
42 & Del/Ins/Dup & 4874dup & Asp1626Glyfs*5 & [41] \\
45 & Del/Ins/Dup & 5304_5305insG & Tyr1769Valfs*36 & C-terminus & [15] \\
46 & $\mathrm{~T}$ & 5446C>T & $\begin{array}{c}\text { Arg1816stop (R1827stop } \\
\text { in Figures) }\end{array}$ & C-terminus & [114,124] \\
47 & Del/Ins/Dup & 5632delC & His1878Metfs*43 & C-terminus & [17] \\
\hline
\end{tabular}

[15], often seen in cone dysfunction syndromes [2]. Due to the phenotypic variability seen in CSNB2 patients, the only diagnostic tool is the electroretinogram (ERG; see also the "Functional phenotyping of Cav1.4 related diseases" section).

In this review, we focus on mutations in the CACNAlF gene as this gene is most commonly affected in CSNB2 patients and their differential effect on retinal visual pathways. We challenge a previously used classification of mutation types and the functional phenotyping strategies currently available. Moreover, we elucidate the influence of different splice variants on Cav1.4 dysfunction and how they might add additional functional impact, and we discuss potential specific therapeutic options for CSNB2 patients.

\section{Role of Cav1.4 channels}

Our understanding of the role of Cav1.4 in the retina largely stems from various mouse models. Up to date, 6 different mouse models are available: two knock-out (KO) models: Cacna1f $\Delta \operatorname{Ex} 7$ and Cacna1f $\Delta$ Ex 14-17, firstly described in $[63,86]$; two spontaneous insertions of a transposable element in exon2 or in the intron of exon 13-14 (nob2 [21] and nob9 mice [25]); the knock-in of the single gain of function point mutation Cav1.4 Ile756Thr (I756T; called Ile745Thr in the original report, corresponding to reference sequence AJ006216, [86]) and a most recently reported non-transmitting G369i knock-in mouse [61].

All those animal models showed that in the absence of functional Cav1.4 channels photoreceptor ribbon synapses remained mostly immature, as evidenced by their roundish (sometimes elongated) appearance (Fig. 2, [58, 61, 77, 79, 118]). In the case of changes in the dynamics of $\mathrm{Ca}^{2+}$ influx, e.g., in I756T mice which carry a gain-of-function Cav1.4 channel mutation [35]. The maturation of photoreceptor synaptic ribbons is disturbed and comes along with free-floating ribbons (Fig. 2). The integrity of other proteins of the ribbon and the arciform density are compromised accordingly in this mouse model $[79,86]$. The non-transmitting G369i knock-in model, however, taught us that although leading to shorter ribbons, the presynaptic assembly of rod synapses can proceed without Cav1.4 meditated $\mathrm{Ca}^{2+}$ signals (Fig. 2, [61]). Together, those data support a dual role of presynaptic Cav1.4 channels: they serve as a source of $\mathrm{Ca}^{2+}$ ions and play an important role as synaptic organizer proteins in the synapse of the visual pathway. Accordingly, Cav1.4 dysfunction leads to postsynaptic changes like sprouting of bipolar and horizontal cell dendrites (Fig. 2) comparable to the KO phenotype of the protein bassoon, which links the ribbon and the arciform density/plasma membrane compartment containing Cav1.4 channels (for review [78]). Moreover, reduced amounts of appropriate synaptic scaffolds, such as PSD-95 in the KO retina [63], may not only limit the retention of Cav1.4 channels in the presynaptic membrane but also affect the correct positioning of postsynaptic proteins. Sprouting is always seen in case of a pronounced change in $\mathrm{Ca}^{2+}$ influx (either KO or gain of function I756T). But whenever Cav1.4 protein was present (at least some), invaginating contacts have been preserved (Fig. 2). Synaptic defects might therefore not only correlate with the extent to which presynaptic Cav1.4 channels are lost (this is also the case when auxiliary subunits of Cav1.4 LTCCs are missing [49, 105]) but also with $\mathrm{Ca}^{2+}$ dynamics (see below, Fig. 3).

\section{Spectrum of Cav1.4 mutations}

Variations in the clinical manifestation of CSNB2 might arise from the different types of Cav1.4 mutations causing different channel defects. Various studies in heterologous expression systems showed that the spectrum of Cav1.4 dysfunction is indeed wide [20, 35, 37, 38, 64, 74, 84].

So far, we framed Cav1.4 mutations in the canonical categories "gain-of-function," "loss-of-function," and "CTM-function impaired" [89]. Nevertheless, while from a biophysical point of view a higher current density is a clear gain of channel function (and vice versa), the definition does not reflect what happens in the (mouse) retina. For example, in I756T (gain-of-function: hyperpolarizing 
Fig. 2 Dual role of Cav1.4 channels in the photoreceptor synapse. Presynaptic Cav1.4 channels serve as sources of $\mathrm{Ca}^{2+}$ ions and play a role as synaptic organizer protein. $\mathrm{Ca}^{2+}$ influx $\left(\mathrm{I}_{\mathrm{Ca}}\right)$ changes according to the Cav1.4 mutation (KO, loss-of-function [58]; G369i, non-conducting [61]; I756T, gain-of-function [35]) and exerts different structural effects: left: the presence of sprouting second order neurons (BC, bipolar cell; HC, horizontal cell) and right: changes in the ribbon structure. The inset shows the lateral view on mature (horseshoe-shaped) and immature (round or elongated) ribbons. In knock-out and I756T retinas synaptic terminals were not only located in the outer plexiform layer (OPL) but were also displaced in the outer nuclear layer (ONL) [51, 58, 120]
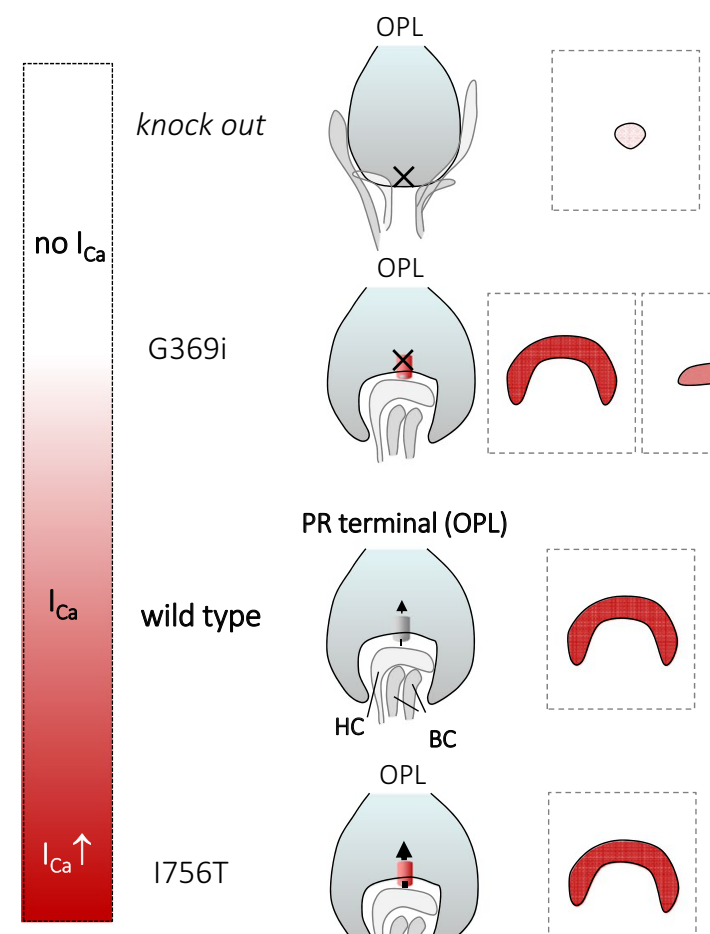

Displaced (ONL)
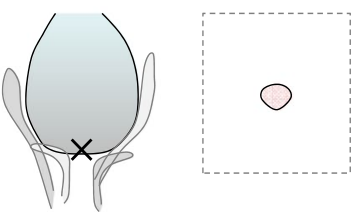

G369i

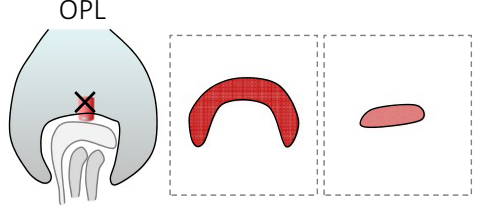

Ribbon structure

Mature

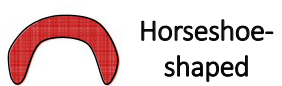

PR terminal (OPL)
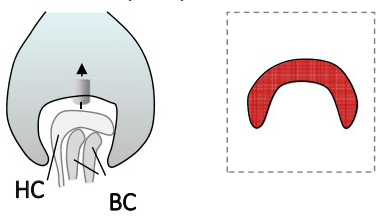

Immature

$\bigcirc$ round

wild type
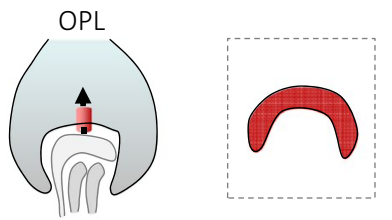

Displaced (ONL)

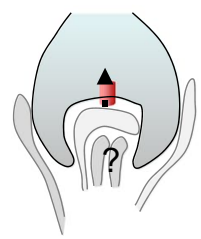

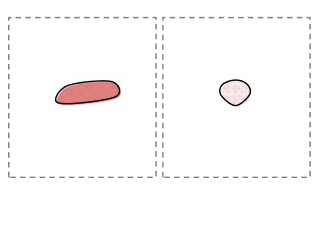

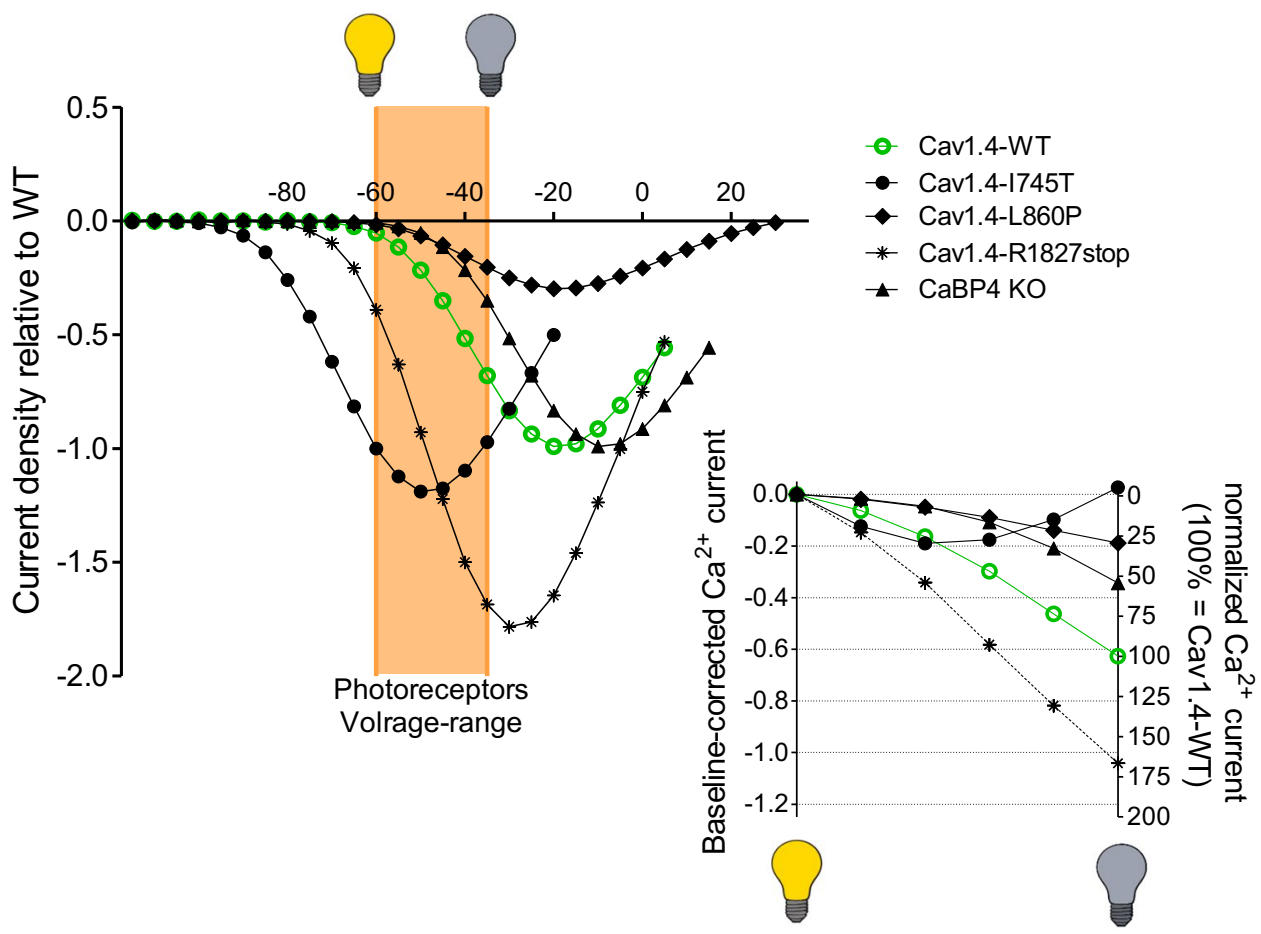

Fig. 3 Cav1.4 mutations lead to a change in the $\mathrm{Ca}^{2+}$ dynamics within the photoreceptor voltage range. The current density of different Cav1.4 CSNB2-mutation relative to wild-type Cav1.4 channels (Cav1.4-WT, green) is indicated. $\mathrm{Ca}^{2+}$ currents measured in rod photoreceptors are the reference for the voltage dependence of Cav1.4 wild-type currents ([5]). Current densities were taken from literature: wild type: open circles, $2 \mathrm{mM} \mathrm{Ca}^{2+}[20]$ (set as-1); I756T: filled circles, $5 \mathrm{mM} \mathrm{Ca}^{2+}$ [35]; L860P: diamonds, $15 \mathrm{mM} \mathrm{Ca}^{2+}$ [20]; R1827stop: stars, $2 \mathrm{mM} \mathrm{Ca}{ }^{2+}$ [20]; CaBP KO: triangles, $20 \mathrm{mM}$ $\mathrm{Ca}^{2+}[72]$. The photoreceptor voltage range is highlighted in orange: from $\sim-60 \mathrm{mV}$ upon light on to $\sim-35 \mathrm{mV}$ at light off. The inset shows currents that were baseline corrected to highlight the change in $\mathrm{Ca}^{2+}$ influx within the photoreceptor voltage range 
shift of the half-maximal voltage of activation $\left(\mathrm{V}_{1 / 2}\right)$ and higher current density; circle in Fig. 3) and the nob2 (lossof-function: reduction of channel surface expression, comparable to the previously characterized L860P, diamond in Fig. 3), retinas are not only virtually undistinguishable from a morphological point of view, but also their ERGs are comparable as scotopic and photopic b-wave are reduced to a similar extent $[21,50]$. It seems that more than the amount of $\mathrm{Ca}^{2+}$ influx, the relative change of $\mathrm{Ca}^{2+}\left(\Delta \mathrm{Ca}^{2+}\right)$ within the photoreceptor voltage range (Fig. 3) is an important readout. Mimicking a loss of function mutation, also the CaBP4 KO mouse was validated as a model for CSNB2 [72]. In vitro, co-expression of Cav1.4 with CaBP4 leads to a $10 \mathrm{mV}$ hyperpolarizing shift compared to Cav1.4 alone [72, 82]. In photoreceptors lacking $\mathrm{CaBP} 4$, this would mean a reduction of $\Delta \mathrm{Ca}^{2+}$ influx within the photoreceptor voltage range of about 50\% (up-triangle in Fig. 3) that could explain the CSNB2 phenotype. Burtscher and colleagues characterized another human Cav1.4 mutation leading to an impairment of the CTM, named R1827stop. This mutation not only shows gain-of-function features but also changes the channel inactivation properties unmasking CDI due to the loss of functional CTM [20]. Mutations that affect the CTM will rather not support continuous $\mathrm{Ca}^{2+}$ influx [20] and might thereby reduce the dynamic range of photoreceptors. Truncations downstream of the CDI machinery in the Cav1.4 C-terminus-physiologically by alternative splicing [95] or introduced by an artificial mutation [84, 102]—are catching our further interest (see also the "Regulation of Cav1.4 function by alternative splicing" section). In addition to a more hyperpolarized activation voltage, Cav1.4R1827stop shows increased current density due to the higher open probability of the channel $[16,20]$. Of note, the mutation does not affect the unitary conductance of the channel $[16,20]$ but whether the number of channels expressed in the plasma membrane is increased has not yet been investigated in any of the Cav1.4 gain-of-function mutations reported. Together these gating changes are resulting in a change in $\Delta \mathrm{Ca}^{2+}$ (asterisks in Fig. 3). Since we are lacking data from in vivo models, it is still unclear which of these processes dominates the phenotype of Cav1.4 mutants with impaired CTM function. Thus, this peculiar mutation will be worth being studied in retinal photoreceptors to gain better understanding of how changes in $\mathrm{Ca}^{2+}$ dynamics affect this ribbon synapse.

\section{Functional phenotyping of Cav1.4 related diseases}

ERGs of CSNB2 patients show that both, scotopic and photopic responses, are affected. Patients present with an abnormal dim scotopic ERG and a typical negative bright-flash
ERG with large a-waves, but severely reduced b-waves; oscillatory potentials are missing. This ERG phenotype, in particular the reduction in the b-wave in both scotopic and also photopic ERG, highlights the transmission problem from rod and cone photoreceptors to bipolar cells (for review, see [124]).

It is a common scientific agreement that Cav1.4 $\alpha 1$ together with the accessory $\beta 2$ and $\alpha 2 \delta 4$ subunits form the major LTCC complex at the photoreceptor terminal (Fig. 1) that mediates $\mathrm{Ca}^{2+}$ influx and consequently regulates glutamatergic vesicle release in both rods and cones. While in all KO models of the abovementioned subunits the b-wave was almost completely absent in both scotopic and photopic ERG recordings [9, 103, 105], in other CSNB2 mouse models the readout was more complicated. In fact, a body of literature highlights the differences between rod and cone photoreceptors in retinal disease $[29,49,61,105$, 118]. In particular, the cone morphology appears to be less affected in CSNB2 models compared to rods [8, 49, 105, 118]. However, the photopic ERG is also severely affected (for review, see [124]). For mutations that lead to changes in the gating properties of the channels the reason may be found in different mechanisms to cope with intracellular $\mathrm{Ca}^{2+}$ concentration (Fig. 3, but see also [48]). Still, further important information regarding specific retinal (dys) function might come with ERG protocols better suited than common ones to investigate separately different pathway (e.g., ON, OFF, [96]). This differentiation would be important because de- and hyperpolarizing bipolar cells do not only express different postsynaptic receptor pools but also take different positions in the triad synapse (e.g., OFF bipolar cell show non-invaginating, flat contacts) and might therefore be differentially affected by presynaptic mutations. In the nob2 mouse model, where only $10 \%$ of Cav1.4 full-length transcript is predicted to be expressed, both light-adapted and dark-adapted ERGs are present [21]. Of note, Chang and colleagues implemented their ERG finding with more sensitive extracellular in vivo single-unit retinal ganglion cell recordings which showed a lower spontaneous activity and a change in the gain of their light response in ON ganglion cells whereas OFF ganglion cell responses were actually unaffected. Thus, we need more appropriate diagnostic tools because the relative preservation of the OFF pathway is most likely undetected in the ON-dominant ERG flash as is the influence of other pathways in the dark-adapted ERG. This is supported by another recent study that emphasized the different effects of a Cav1.4 mutation in the scotopic and photopic retinal pathways. In fact, in I756T mice, the cone-cone bipolar cell transmission was severely affected whereas the rod pathway was still responding to light [120].

Moreover, in the non-transmitting G369i mutant in which the morphology of the ribbon synapse is largely maintained the ERG highlighted a positive b-wave at high 
light intensities [61]. By contrast, no discernible b-wave can be detected in Cav1.4 KO mice [67], comparable to mice completely lacking rod and cone phototransduction [23], ruling out intrinsically photosensitive ganglion cells as the source of this ERG $b$-wave. This finding suggests that (i) cones might express also other $\mathrm{Ca}^{2+}$ channels in addition to Cav1.4 and (ii) some residual vision might be present and is worth investigating. It is therefore imperative to solve the channel (subunit and/or splice variant) composition of rods and cones to be able to better understand CSNB2 pathology.

\section{Regulation of Cav1.4 function by alternative splicing}

Alternative splicing is a common feature of voltage-gated $\mathrm{Ca}^{2+}$ channel subunits thought to confer an increased diversity to the biophysical properties and potential interactions of the channel. Among $\alpha 1$, the extent of Cav1.2 and Cav1.3 alternative splicing also correlates with their widespread tissue distributions (including heart, vascular smooth muscle, endocrine cells, and neurons in the nervous system) compared to the narrow expression patterns of Cav1.1 (largely specific for skeletal muscle) and Cav1.4 (mainly in the retina). This difference suggests potentially less necessity for differential tuning of channel properties for the latter two isoforms. Nonetheless, several Cav1.4 splice variants have been determined in mRNA isolated from the human retina and some of them have been functionally characterized (Fig. 1, Table 2, [33, 95]).

Table 2 Productive Cav1.4 splice variants found in human retina. We excluded splice variants that can be considered non-productive (inducing frameshifts and premature stops or otherwise leading to deletions of transmembrane segments, including the double frameshifts around exons 16-18). The \% of each variant at respective locus was taken from Tan et al. (2012) [95] (\#) and Haeseleer et al.
Unsurprisingly, the variants leading to substantial deletions in the C-terminus including the CTM (Ex43* and $\Delta \mathrm{Ex} 47)$ exhibit pronounced CDI, likely through facilitated CaM binding to the IQ domain region (Fig. 1, [108]). In addition, both variants also impose a marked hyperpolarizing shift of their $\mathrm{V}_{1 / 2}$. The abundantly expressed Ex45a(called $\Delta$ ex p45 in [33]), with only a minor shortening of the C-terminal sequence, has little to no effect on the current-voltage (I-V) relationship or CDI properties. Similarly, the Ex42d + variant exhibits little change relative to the canonical variant's biophysical properties; however, this variant has only been studied in a chimeric channel [95]. Both Ex45a- and Ex42d + don't affect the putative PCRD/DCRD sequences, thus no effects on $\mathrm{CDI}$ are expected. The $\Delta \mathrm{Ex} 32$ variant in the IVS3-IVS4 linker has also only been studied in a chimera but exhibited a substantial hyperpolarizing shift of the I-V curve (effects on VDI or CDI were not tested, [59]). Of note, pharmacological properties can be modulated by alternative splicing, seen for example in the sensitivity of C-terminal Cav1.3 splice variants for dihydropyridines (DHP) [42]. There is no published data on pharmacological properties of different Cav1.4 splice variants to date.

The interplay between mutations and splice variants is an important aspect for the understanding of the functional impact that splicing might have on a mutated channel. Thus far the effect of splice variants on the function of channels harboring a mutation and the pathology caused has been largely understudied. An example of a systematic comparison has been performed by Hofer and colleagues [39], where the biophysical properties of the S652L mutation in Cav1.3 were compared between the full-length channel and a short

(2016) [33] (\#\#). Changes in activation and inactivation properties are provided where data is available. Data sources: \#1 [95] (Cav1.2 chimera), \#2 [95], \#\# [33], \#\#\# Liu et al. (2017) [59] (Cav1.3 chimera); $V_{I / 2}$, shift in the half-maximal voltage of activation; VDI, voltagedependence of inactivation; $\mathrm{CDI}, \mathrm{Ca}^{2+}$-dependence of inactivation

\begin{tabular}{|c|c|c|c|c|}
\hline \multirow[t]{2}{*}{ Splice variant } & \multirow[t]{2}{*}{$\%$ at locus } & \multirow[t]{2}{*}{ Structural change } & \multicolumn{2}{|c|}{ Functional characterization } \\
\hline & & & Activation $\left(\mathrm{V}^{1} / 2\right)$ & Inactivation \\
\hline $\operatorname{Ex} 2 x$ & $3.4 \%{ }^{\#}$ & $\mathrm{~N}$-terminal sequence changed (mutually exclusive in-frame exon) & n.a & n.a \\
\hline Ex9d- & $9.1 \%{ }^{\#}$ & $\begin{array}{l}\text { shorter I-II linker, preserved AID (in-frame alternative splice donor site; } \\
\Delta \text { GSMAEEGRAGH) }\end{array}$ & n.a & n.a \\
\hline$\Delta \mathrm{Ex} 32$ & $17.9 \%$ \# & shorter IVS3-IVS4 linker (in-frame exon skipping; $\Delta$ NGGHLGE) & $\leftarrow \leftarrow(-7 \mathrm{mV})^{\# \# \#}$ & n.d. \#\# \\
\hline Ex42d+ & n.a & $\begin{array}{l}\text { C-terminal sequence changed; longer C-terminus (in-frame alternative splice } \\
\text { donor site; + VGTSFHSPRNLI) }\end{array}$ & $\leftarrow(-2.6 \mathrm{mV})^{\# 1}$ & unchanged $^{\# 1}$ \\
\hline Ex $43 *$ & $13.6 \%{ }^{\#}$ & $\begin{array}{l}\text { C-terminal sequence changed; shorter C-terminus, CTM deleted (novel exon } \\
\text { with stop; + SRDEVLPCWPGWFRTPDLR) }\end{array}$ & $\leftarrow \leftarrow(-12.5 \mathrm{mV})^{\# 2}$ & $\begin{array}{l}\mathrm{VDI} \downarrow \\
\mathrm{CDI} \uparrow \uparrow 2\end{array}$ \\
\hline Ex45a- & $\begin{array}{l}12.7 \%^{\#} \\
13.8 \%^{\# \#}\end{array}$ & $\begin{array}{l}\text { C-terminal sequence changed; shorter C-terminus (in-frame alternative } \\
\text { splice acceptor site; } \Delta \text { LSYLDEQAGTPPCSVLLPPHR) }\end{array}$ & $\begin{array}{l}\rightarrow(1.2 \mathrm{mV})^{\# 1} \\
\leftarrow(-3.0 \mathrm{mV})^{\# \#}\end{array}$ & unchanged $^{\# 1, \# \#}$ \\
\hline$\Delta \mathrm{Ex} 47$ & $<2 \% \#$ & $\begin{array}{l}\text { proximal CTM (PCRD) deleted (in-frame exon skipping; } \triangle \text { GSWATPPQRG } \\
\text { RLLYAPLLLVEEGAAGEGYLGRSSGPLRTFTCLHVPGTHSDPSHGK } \\
\text { RGSADSLVEA) }\end{array}$ & $\leftarrow \leftarrow(-8.0 \mathrm{mV})^{\# \#}$ & $\begin{array}{l}\text { VDI normal, } \\
\text { CDI } \uparrow^{\uparrow \#}\end{array}$ \\
\hline
\end{tabular}


variant, lacking a large part of the $\mathrm{C}$-terminus, including the Cav1.3 CTM. Most mutation-induced changes were similar in both variants; however, CDI was reduced only in the short variant. The only study of alternative splicing with a mutation in Cav1.4 investigated splice variant-dependent effects of the I756T mutation by comparing the mutation effect on canonical full-length Cav1.4 with the variant lacking exon 47 ( $\Delta \mathrm{Ex} 47)$ [109]. The authors found comparable hyperpolarizing shifts of the $\mathrm{V}_{1 / 2}$ induced by the I756T mutation in full-length $(-20 \mathrm{mV})$ and $\Delta \mathrm{Ex} 47(-19 \mathrm{mV})$ channels but a substantial reduction of current density only for $\Delta \mathrm{Ex} 47$ $(\sim 75 \%)$, with effects of the splice variant also on current kinetics, especially on the time constant of deactivation. The interesting aspect of these splice variant-dependent effects of the mutation lies in the cumulative nature of the $\mathrm{V}_{1 / 2}$ change, leading to an additive hyperpolarizing shift that results in a very negative activation threshold for I756T- $\Delta \mathrm{Ex} 47$. Consequently, mutations can not only have different effects on channel properties depending on the splice variant but also changes due to splice variant and mutation can be cumulative and thus cause an exacerbation of the effects.

Interestingly, some effects might not just be modulated by the splice variant but can indeed only affect specific splice variants, for example when a mutation is localized inside a cassette exon or inside one of several mutually exclusive exons. For example, Cav1.2 mutations in patients with Timothy syndrome (TS) can be localized in either one of its mutually exclusive exons 8 a (TS1) or 8 (TS2), leading to specific effects depending on whether the mutationcarrying exon is expressed in the tissue of interest [87]. Of the Cav1.4 mutations published so far, this effect can potentially occur with mutations in exon 2 for which an alternative exon exists (Ex2x, [95]) and is therefore likely not of major concern for the understanding of pathological changes of Cav1.4 channel function.

\section{Regulation of Cav1.4 function by subunit composition}

What is of high relevance for our understanding of functional changes imposed by mutations is the auxiliary subunit composition of Cav1.4 channel complexes. Luckily, there seems to be limited diversity in auxiliary subunit expression in retinal photoreceptors with both rods and cones expressing $\alpha 2 \delta 4$ and $\beta 2$. For both of these isoforms, there are limited reports on alternative splicing, with one study showing a truncating variant of $\alpha 2 \delta 4$ in the retina [7] and another study detecting the expression of a subvariant of $\beta 2 a$, called $\beta 2 \mathrm{X} 13$, that differs in the inclusion of exon $7 \mathrm{~B}$ instead of the common exon 7A [56]. Most importantly, a recent publication showed different biophysical properties of the I756T mutation in channel complexes made from $\beta 2 \mathrm{a}$ and $\alpha 2 \delta 1$ in comparison with the published native composition with $\beta 2 X 13$ and $\alpha 2 \delta 4$ [109]. While parameter changes were qualitatively the same in both complex compositions, mainly a marked hyperpolarizing shift of the $\mathrm{V}_{1 / 2}$ induced by the I756T mutation, the magnitudes were different and distinctly dependent on Cav1.4 splice variant. In particular, a difference in the activation gating between full-length Cav1.4 and $\Delta$ Ex47 carrying the I756T mutation was only apparent with $\beta 2 \mathrm{X} 13$ and $\alpha 2 \delta 4$. Crucially, the loss of $\mathrm{Ca}^{2+}$-selectivity in I756T-mutated Cav1.4 that they observed was dependent on co-expression with $\beta 2 \mathrm{X} 13$ and $\alpha 2 \delta 4$ and was absent with $\beta 2 \mathrm{a}$ and $\alpha 2 \delta 1$ [109].

There is to date no definite proof for cell-type specific splicing of Cav1.4 and/or auxiliary subunits in rods versus cones (or bipolar cells), which has several important consequences. Distinct splice variant-dependent mutation effects could, however, have a deeper impact on one of the cell types. One piece of evidence for a differential expression of Cav1.4 splice variants might be found from pharmacological studies. Neuromodulators like nitric oxide, somatostatin, or dopamine modulate $\mathrm{Ca}^{2+}$ currents in rod and cone photoreceptors differently $[3,54,88]$, which could derive from a difference in the composition of $\mathrm{Ca}^{2+}$ channel complexes or Cav1.4 splice variants.

In summary, the definitive impact of a Cav1.4 mutation is dependent on the auxiliary subunit composition of the channel complex and on the Cav1.4 splice variant that is expressed. Until now, we only know of the existence of splice variants but we do not know if several variants are co-expressed by some cell type(s) or whether each variant has a distinct cell type of origin. There is clearly a need to determine the Cav1.4 splice variant expression in different retinal cell types to lay the foundation for an understanding of how disease-causing mutations would be modified by this factor. In heterologous expression systems, we should then consider the potential variability due to the Cav1.4 splice variant used and, in particular, also the auxiliary subunits that are co-expressed. Finally, the splice variant influence is of relevance for gene supplementation therapy approaches, where one consensus variant would be supplemented to all cell types which might not be the ideal fit for the native function in cells normally expressing an alternative Cav1.4 variant.

\section{Pharmacology of Cav1.4 channels}

The DHP sensitivity of LTCCs varies between tissues, most likely due to not only their differential Cav and accessory protein expression but also alternative splicing of $\alpha 1$ subunit (see the "Regulation of Cav1.4 function by alternative splicing" section, [42]). Consistent with the $\mathrm{Ca}^{2+}$ channel pharmacology in photoreceptors, which previously suggested a 
low affinity for DHPs [107], Cav1.4 exhibits about fivefold lower sensitivity to DHPs than Cav1.2 at negative membrane potentials [52, 69, 116]. Still, compared to other LTCCs (Cav1.2/Cav1.3), the Cav1.4 pharmacology has been poorly studied and further work will be required before high-affinity $\mathrm{Ca}^{2+}$ channel blockers could be efficiently applied (for review, see [119]). Of note, the DHP sensitivity for mutated channels should be studied separately as some Cav1.3 variants showed different affinity to DHPs compared to the wild type $[39,76]$. As a matter of fact, the I756T mutation showed a tenfold higher sensitivity to the DHP nilvadipine compared to wild-type Cav1.4 [120]. Zanetti and colleagues tried to revert the retinal phenotype caused by the gain of function mutation I756T with acute application of the drug in ex vivo retina. While this approach was not effective, in vivo long treatment with low-dose $\mathrm{Ca}^{2+}$ channel blockers could still be beneficial.

Instead, due to toxic side effects expected from activation of Cav1.2 and Cav1.3 in other tissues, pharmacological activation of mutated Cav1.4 channels (still expressed but with strongly reduced current density because of e.g. increased protein turnover but unchanged single channel properties [20] by LTCC activators (e.g., BayK8644)) would not be clinically applicable to humans (for review see [119]). Gating modifying drugs that would change activation and inactivation channel properties are currently not available but are on demand to optimize the dynamic range of $\mathrm{Ca}^{2+}$ signaling in retinal photoreceptors expressing Cav1.4 channel mutations (Fig. 3).

\section{Options for targeted therapies in congenital stationary night blindness type 2}

A milestone that cleared a path for new therapies targeting retinal diseases in clinical trials was the approval of Luxturna ${ }^{\circledR}$, the first gene therapeutic drug used for the retinal dystrophy Leber congenital amaurosis type 2 [62]. Viral vectors as vehicles to transport genetic information into cells have been employed extensively in the gene therapeutic field [60].

Most of the current retinal gene therapies are employing recombined adeno-associated virus (rAAV) vectors due to the lack of human pathogenesis and the low immune response compared to other viral vectors [13]. However, all of the current clinical trials employing rAAVs transport small genes because the efficient packaging capacity is below 5000 base pairs $[28,112]$. Thus, to circumvent the size limitation of AAVs transporting bigger genes (e.g., $C A C N A 1 F$ ), different procedures such as intermolecular recombination, RNA-, and protein trans-splicing are needed $[91,97,98]$.
Cav1.4 mutations leading to fewer functional channels, due to decreased channel stability and promoted misfolding ([20], for review see [89]), would be a perfect target for augmentation gene therapy. As an example, we predicted the structural consequences of a glycine to valine mutation located extracellularly at the end of the IVS5 transmembrane helix in the voltage sensor domain (VSD) IV (G1350V) by building a homology model based on the cryo-electron microscopy structure of the Cav1.1 $\alpha 1$ subunit in the inactivated state (PDB accession code: 5GJW) [113]); sequence similarity with Cav1.4 $\alpha 1$ about $85 \%$; Fig. 4). As G1350 is located at the beginning of the pore loop; it introduces mobility which might be required for forming the kink of the pore loop (Fig. 4b, c). The mutation might therefore destabilize a favorable interdomain interaction of the G1350 with the neighboring VSD III (Fig. 4d, e) resulting in a lower open probability and/or decrease of the stability of the channel (previously also observed for the intracellularly located loss of function mutation L860P, [20]). Interestingly, a similarly located mutation in the segment S6 of the Cav1.2 VSD I - that might also form an interaction with the pore loop-is a causal long QT syndrome mutation [30]. Such mutations would benefit from the application of chemical chaperones because the gating properties of the remaining currents are comparable to wild type ([20], Fig. 3 for L860P). A majority of mutations, however, are predicted to cause severe structural changes such that they are unlikely to form functional channels, often due to premature truncation (Table 1). Truncated Cav1.4 channels might therefore not even be expressed because nonsense-mediated mRNA decay eliminates mRNAs containing premature translationtermination codons [18].

Gene augmentation therapy, however, might not be practical for all Cav1.4 mutations. In case of mutations that cause gating changes, inhibitory RNA could be expressed in photoreceptor cells to bind to the mutation-containing mRNA and initiate RNA degradation [75, 94]. This procedure would lead to a decrease in non-functioning protein product and may be beneficial for cell survival if combined with a gene supplementation therapy.

Furthermore, errors in the splicing procedure of premRNA might change the functionality of the translated protein (Table 3). Here, antisense oligonucleotides can be used to increase the likelihood of excluding or including individual exons during the splicing process $[6,31]$ and thereby restore a wild-type coding sequence. Lastly, an additional way to treat Cav1.4 mutations could be to correct them in the photoreceptor genome using zinc finger nucleases [99], TALENs [111], or CRISPR/Cas [36, 92] as molecular tools.

Currently, no gene therapy for CSNB2 is available. However, Waldner and colleagues established a mouse line that showed a partial structural and functional rescue of retinal integrity by cre-induced expression of a transgenic Cav1.4 

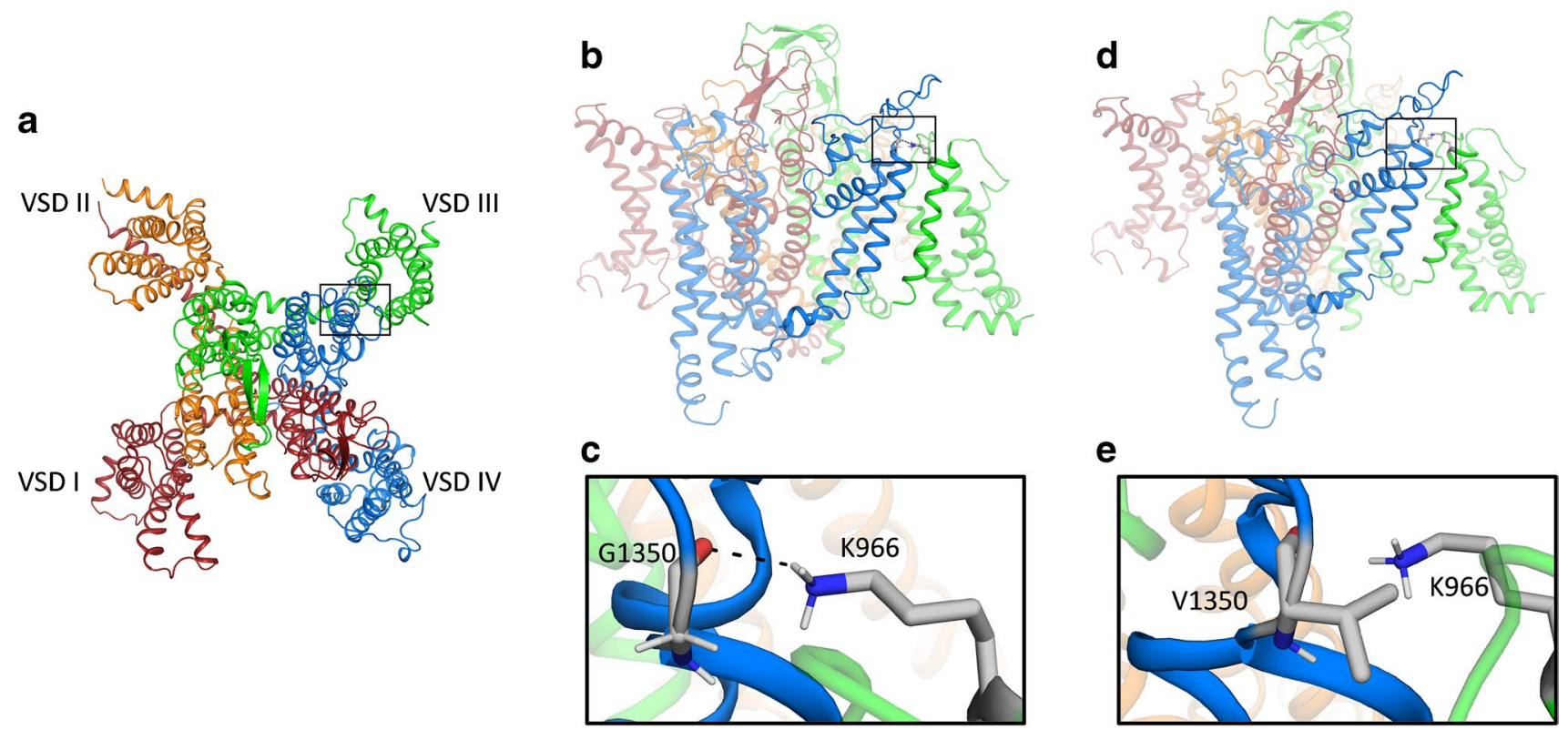

Fig. 4 Structure model of the wild type and the G1350V mutant Cav1.4 $\alpha 1$ subunit. Panel a: top view of the Cav1.4 $\alpha 1$ subunit, highlighting the position of the G1350V mutation, which is located at the end of the IVS5 transmembrane helix. Panels $\mathbf{b}$ and $\mathbf{c}$ illustrate the

[104]. Cre expression was controlled by a Pax6 promoter, resulting in Cav1.4 expression in the early developmental stage. Of note, ERGs and visually evoked potentials in the visual cortex supported signal transduction to the brain.

Table 3 Location and nucleotide position of so far uncharacterized splice site mutations

\begin{tabular}{lll}
\hline Exon or exon-exon & Nucleotide & Reference \\
\hline $3-4$ & c. $382-2 \mathrm{~A}>\mathrm{G}$ & {$[96]$} \\
$4-5$ & $\mathrm{c} .523-2 \mathrm{~A}>\mathrm{G}$ & {$[96]$} \\
17 & $\mathrm{c} .2288+1 \mathrm{G}>\mathrm{A}$ & {$[22]$} \\
17 & $\mathrm{c} .2288+5 \mathrm{G}>\mathrm{T}$ & {$[22]$} \\
19 & $\mathrm{c} .2387-1 \mathrm{G}>\mathrm{C}$ & {$[97]$} \\
20 & $\mathrm{c} .2544-1 \mathrm{G}>\mathrm{A}$ & {$[22]$} \\
20 & $\mathrm{c} .2571+1 \mathrm{G}>\mathrm{C}$ & {$[101]$} \\
21 & $\mathrm{c} .2673+3 \mathrm{G}>\mathrm{A}$ & {$[97,98]$} \\
21 & $\mathrm{c} .2674-2 ; 2674-3$ delCA & {$[97]$} \\
22 & $\mathrm{c} .2733+1 \mathrm{G}>\mathrm{C}$ & {$[101]$} \\
24 & $\mathrm{c} .2938+1 \mathrm{G}>\mathrm{A}$ & {$[96,98]$} \\
$24-25$ & $\mathrm{c} .2961+1 \mathrm{G}>\mathrm{A}$ & {$[96]$} \\
28 & $\mathrm{c} .3439-1 \mathrm{GCGTC}>\mathrm{TGG}$ & {$[47]$} \\
33 & c. $3942+2 \mathrm{~T}>\mathrm{C}$ & {$[97]$} \\
33 & c. $3942+2 \mathrm{~T}>\mathrm{A}$ & {$[97]$} \\
35 & c. $4101-1 \mathrm{G}>\mathrm{C}$ & {$[22,97]$} \\
39 & c. $4590-2 \mathrm{~A}>\mathrm{G}$ & {$[96]$} \\
$40-41$ & c. $4724-2 \mathrm{~A}>\mathrm{G}$ & {$[96]$} \\
\hline
\end{tabular}

interdomain interaction of VSD III (K966) with the pore loop of VSD IV (G1350) the wildtype Cav1.4 $\alpha 1$ subunit which cannot be formed between V1350 and K966 (d, e)

Immunohistochemical analysis of the transgene revealed patchy expression throughout the retina. Since the integration of the transgene into the genome should be at the same locus for all nucleus-containing cells, the patchy expression pattern hints to either epigenetic silencing or post-transcriptional degradation. The structural features of the retina resembled a mosaicism phenotype, in which columns show either the knockout or the wild-type phenotype. Michalakis and colleagues reported a similar phenotype in Cav 1.4 heterozygous female mice, caused by X-chromosome inactivation [65]. Avoiding genomic silencing is of crucial interest for a retina-wide expression of the transgene. A possible strategy could be to employ the CRISPR/Cas system to guide methyl-cleaving proteins to the genomic integration site of the transgene and carry out epigenetic editing by removing the methylation labels responsible for the gene inactivation [26]. One option might be to flank the transgene with insulator sequences; in between those genomic DNA is known to be better accessible and transcriptionally active, resulting in long-term expression in vivo [22, 93]. Another option would be to target the transgene into known genetic safe harbor locations, where gene silencing is not expected (e.g., the AAVS1 locus, for review, see [71]).

Laird and colleagues, on the other hand, employed a tamoxifen-inducible promoter to temporally express transgenic Cav1.4 [55]. Rods got transfected with transgenecarrying plasmids by retinal in vivo electroporation at the day of birth because rod-precursor cells are still dividing at 
that developmental stage and plasmid DNA can enter the nucleus during mitosis. In both young and mature animals, induction of Cav1.4 expression partially rescued synaptic features. Most likely due to the low transfection rate of rods, which was $10 \%$, the ERG could not be restored. Thus, the performance improvement in a visually guided water maze test was limited. Yet there are technical difficulties to be overcome because of retinal detachment observed in the tamoxifen-induced group.

Taken together, a gene therapeutic approach will bring us closer to a better understanding of the role of Cav1.4 channel for synapse plasticity and pave the way for clinical applications in human patients.

Funding Open access funding provided by University of Innsbruck and Medical University of Innsbruck. This project was supported by the Austrian Science Fund (FWF P-32747, DOC 30 to AK, P-33566 to HS), the Center of Molecular Biosciences Innsbruck, and the University of Innsbruck.

\section{Declarations}

Conflict of interest The authors declare no competing interests.

Open Access This article is licensed under a Creative Commons Attribution 4.0 International License, which permits use, sharing, adaptation, distribution and reproduction in any medium or format, as long as you give appropriate credit to the original author(s) and the source, provide a link to the Creative Commons licence, and indicate if changes were made. The images or other third party material in this article are included in the article's Creative Commons licence, unless indicated otherwise in a credit line to the material. If material is not included in the article's Creative Commons licence and your intended use is not permitted by statutory regulation or exceeds the permitted use, you will need to obtain permission directly from the copyright holder. To view a copy of this licence, visit http://creativecommons.org/licenses/by/4.0/.

\section{References}

1. Abdelkader E, AlHilali S, Neuhaus C, Bergmann C, AlMurshed T, Schatz P (2018) Congenital stationary night blindness associated with morning glory disc malformation: a novel hemizygous mutation in CACNA1F. Ophthalmic Genet 39:659-661. https:// doi.org/10.1080/13816810.2018.1498526

2. Aboshiha J, Dubis AM, Carroll J, Hardcastle AJ, Michaelides M (2016) The cone dysfunction syndromes. Br J Ophthalmol 100:115-121. https://doi.org/10.1136/bjophthalm ol-2014-306505

3. Akopian A, Johnson J, Gabriel R, Brecha N, Witkovsky P (2000) Somatostatin modulates voltage-gated $\mathrm{K}(+)$ and $\mathrm{Ca} 2+$ currents in rod and cone photoreceptors of the salamander retina. J Neurosci 20:929-936

4. Audo I, Bujakowska KM, Leveillard T, Mohand-Said S, Lancelot ME, Germain A, Antonio A, Michiels C, Saraiva JP, Letexier M, Sahel JA, Bhattacharya SS, Zeitz C (2012) Development and application of a next-generation-sequencing (NGS) approach to detect known and novel gene defects underlying retinal diseases. Orphanet J Rare Dis 7:8. https://doi.org/10.1186/1750-1172-7-8

5. Babai N, Thoreson WB (2009) Horizontal cell feedback regulates calcium currents and intracellular calcium levels in rod photoreceptors of salamander and mouse retina. J Physiol 587:23532364. https://doi.org/10.1113/jphysiol.2009.169656

6. Bacchi N, Casarosa S, Denti MA (2014) Splicing-correcting therapeutic approaches for retinal dystrophies: where endogenous gene regulation and specificity matter. Invest Ophthalmol Vis Sci 55:3285-3294. https://doi.org/10.1167/iovs.14-14544

7. Bacchi N, Messina A, Burtscher V, Dassi E, Provenzano G, Bozzi Y, Demontis GC, Koschak A, Denti MA, Casarosa S (2015) A new splicing isoform of cacna2d4 mimicking the effects of c.2451insC mutation in the retina: novel molecular and electrophysiological insights. Invest Ophthalmol Vis Sci 56:4846-4856. https://doi.org/10.1167/iovs.15-16410

8. Ball SL, Gregg RG (2002) Using mutant mice to study the role of voltage-gated calcium channels in the retina. Adv Exp Med Biol 514:439-450

9. Ball SL, Powers PA, Shin HS, Morgans CW, Peachey NS, Gregg RG (2002) Role of the b2 subunit of voltage-dependent calcium channels in the retinal outer plexiform layer. Invest Ophthalmol Vis Sci 43:1595-1603

10. Bartoletti TM, Jackman SL, Babai N, Mercer AJ, Kramer RH, Thoreson WB (2011) Release from the cone ribbon synapse under bright light conditions can be controlled by the opening of only a few $\mathrm{Ca}(2+)$ channels. J Neurophysiol 106:2922-2935. https://doi.org/10.1152/jn.00634.2011

11. Baumann L, Gerstner A, Zong X, Biel M, Wahl-Schott C (2004) Functional characterization of the L-type $\mathrm{Ca}^{2+}$ channel $\mathrm{Ca}_{\mathrm{v}} 1.4 \mathrm{a} 1$ from mouse retina. Invest Ophthalmol Vis Sci 45:708-713

12. Bech-Hansen NT, Naylor MJ, Maybaum TA, Pearce WG, Koop B, Fishman GA, Mets M, Musarella MA, Boycott KM (1998) Loss-of-function mutations in a calcium-channel alpha1-subunit gene in Xp11.23 cause incomplete X-linked congenital stationary night blindness. Nat Genet 19:264-267. https://doi.org/10.1038/ 947

13. Bennett $J$ (2003) Immune response following intraocular delivery of recombinant viral vectors. Gene Ther 10:977-982. https://doi. org/10.1038/sj.gt.3302030

14. Berntson A, Taylor WR, Morgans CW (2003) Molecular identity, synaptic localization, and physiology of calcium channels in retinal bipolar cells. J Neurosci Res 71:146-151

15. Bijveld MM, Florijn RJ, Bergen AA, van den Born LI, Kamermans M, Prick L, Riemslag FC, van Schooneveld MJ, Kappers AM, van Genderen MM (2013) Genotype and phenotype of 101 dutch patients with congenital stationary night blindness. Ophthalmology 120:2072-2081. https://doi.org/10.1016/j.ophtha. 2013.03.002

16. Bock G, Gebhart M, Scharinger A, Jangsangthong W, Busquet P, Poggiani C, Sartori S, Mangoni ME, Sinnegger-Brauns MJ, Herzig S, Striessnig J, Koschak A (2011) Functional properties of a newly identified C-terminal splice variant of Cav1.3 L-type Ca2+ channels. J Biol Chem 286:42736-42748. https://doi.org/ 10.1074/jbc.M111.269951

17. Boycott KM, Maybaum TA, Naylor MJ, Weleber RG, Robitaille J, Miyake Y, Bergen AA, Pierpont ME, Pearce WG, BechHansen NT (2001) A summary of 20 CACNA1F mutations identified in 36 families with incomplete X-linked congenital stationary night blindness, and characterization of splice variants. Hum Genet 108:91-97

18. Brogna S, Wen J (2009) Nonsense-mediated mRNA decay (NMD) mechanisms. Nat Struct Mol Biol 16:107-113. https:// doi.org/10.1038/nsmb.1550 
19. Buraei Z, Yang J (2010) The ss subunit of voltage-gated Ca2+ channels. Physiol Rev 90:1461-1506. https://doi.org/10.1152/ physrev.00057.2009

20. Burtscher V, Schicker K, Novikova E, Pohn B, Stockner T, Kugler C, Singh A, Zeitz C, Lancelot ME, Audo I, Leroy BP, Freissmuth M, Herzig S, Matthes J, Koschak A (2014) Spectrum of Cav1.4 dysfunction in congenital stationary night blindness type 2. Biochim Biophys Acta 1838:2053-2065. https://doi.org/ 10.1016/j.bbamem.2014.04.023

21. Chang B, Heckenlively JR, Bayley PR, Brecha NC, Davisson MT, Hawes NL, Hirano AA, Hurd RE, Ikeda A, Johnson BA, McCall MA, Morgans CW, Nusinowitz S, Peachey NS, Rice DS, Vessey KA, Gregg RG (2006) The nob2 mouse, a null mutation in Cacna1f: anatomical and functional abnormalities in the outer retina and their consequences on ganglion cell visual responses. Vis Neurosci 23:11-24

22. Ciavatta D, Kalantry S, Magnuson T, Smithies O (2006) A DNA insulator prevents repression of a targeted X-linked transgene but not its random or imprinted X inactivation. Proc Natl Acad Sci U S A 103:9958-9963. https://doi.org/10.1073/pnas.0603754103

23. Claes E, Seeliger M, Michalakis S, Biel M, Humphries P, Haverkamp S (2004) Morphological characterization of the retina of the CNGA3(-/-)Rho(-/-) mutant mouse lacking functional cones and rods. Invest Ophthalmol Vis Sci 45:2039-2048

24. Corey DP, Dubinsky JM, Schwartz EA (1984) The calcium current in inner segments of rods from the salamander (Ambystoma tigrinum) retina. J Physiol 354:557-575

25. Dai X, Pang S, Wang J, FitzMaurice B, Pang J, Chang B (2019) Photoreceptor degeneration in a new Cacnalf mutant mouse model. Exp Eye Res 179:106-114. https://doi.org/10.1016/j. exer.2018.11.010

26. Devesa-Guerra I, Morales-Ruiz T, Perez-Roldan J, Parrilla-Doblas JT, Dorado-Leon M, Garcia-Ortiz MV, Ariza RR, RoldanArjona T (2020) DNA methylation editing by CRISPR-guided excision of 5-methylcytosine. J Mol Biol 432:2204-2216. https:// doi.org/10.1016/j.jmb.2020.02.007

27. Dolphin AC (2012) Calcium channel auxiliary alpha2delta and beta subunits: trafficking and one step beyond. Nat Rev Neurosci 13:542-555. https://doi.org/10.1038/nrn3311

28. Dong B, Nakai H, Xiao W (2010) Characterization of genome integrity for oversized recombinant AAV vector. Mol Ther 18:87-92. https://doi.org/10.1038/mt.2009.258

29. Fairless R, Williams SK, Katiyar R, Maxeiner S, Schmitz F, Diem R (2020) ERG responses in mice with deletion of the synaptic ribbon component RIBEYE. Invest Ophthalmol Vis Sci 61:37. https://doi.org/10.1167/iovs.61.5.37

30. Fukuyama M, Wang Q, Kato K, Ohno S, Ding WG, Toyoda F, Itoh H, Kimura H, Makiyama T, Ito M, Matsuura H, Horie M (2014) Long QT syndrome type 8: novel CACNA1C mutations causing QT prolongation and variant phenotypes. Europace 16:1828-1837. https://doi.org/10.1093/europace/euu063

31. Garanto A, Chung DC, Duijkers L, Corral-Serrano JC, Messchaert M, Xiao R, Bennett J, Vandenberghe LH, Collin RW (2016) In vitro and in vivo rescue of aberrant splicing in CEP290-associated LCA by antisense oligonucleotide delivery. Hum Mol Genet 25:2552-2563. https://doi.org/10.1093/hmg/ ddw 118

32. Griessmeier K, Cuny H, Rotzer K, Griesbeck O, Harz H, Biel M, Wahl-Schott C (2009) Calmodulin is a functional regulator of Cav1.4 L-type Ca2+ channels. J Biol Chem 284:29809-29816. https://doi.org/10.1074/jbc.M109.048082

33. Haeseleer F, Williams B, Lee A (2016) Characterization of C-terminal Splice Variants of Cav1.4 Ca2 + Channels in Human Retina. J Biol Chem 291:15663-15673. https://doi.org/10.1074/ jbc.M116.731737
34. Heidelberger R, Matthews G (1992) Calcium influx and calcium current in single synaptic terminals of goldfish retinal bipolar neurons. J Physiol 447:235-256

35. Hemara-Wahanui A, Berjukow S, Hope CI, Dearden PK, Wu SB, Wilson-Wheeler J, Sharp DM, Lundon-Treweek P, Clover GM, Hoda JC, Striessnig J, Marksteiner R, Hering S, Maw MA (2005) A CACNA1F mutation identified in an X-linked retinal disorder shifts the voltage dependence of Cav1.4 channel activation. Proc Natl Acad Sci U S A 102:7553-7558. https://doi.org/10.1073/ pnas.0501907102

36. Hirakawa MP, Krishnakumar R, Timlin JA, Carney JP, Butler KS (2020) Gene editing and CRISPR in the clinic: current and future perspectives. Biosci Rep 40. https://doi.org/10.1042/ BSR20200127

37. Hoda JC, Zaghetto F, Koschak A, Striessnig J (2005) Congenital stationary night blindness type 2 mutations S229P, G369D, L1068P, and W1440X alter channel gating or functional expression of Cav1.4 L-type Ca2+ channels. J Neurosci 25:252-259

38. Hoda JC, Zaghetto F, Singh A, Koschak A, Striessnig J (2006) Effects of congenital stationary night blindness type 2 mutations R508Q and L1364H on Cav1.4 L-type Ca2+ channel function and expression. J Neurochem 96:1648-1658. https://doi.org/10. 1111/j.1471-4159.2006.03678.x

39. Hofer NT, Tuluc P, Ortner NJ, Nikonishyna YV, FernandesQuintero ML, Liedl KR, Flucher BE, Cox H, Striessnig J (2020) Biophysical classification of a CACNA1D de novo mutation as a high-risk mutation for a severe neurodevelopmental disorder. Mol Autism 11:4. https://doi.org/10.1186/s13229-019-0310-4

40. Hope CI, Sharp DM, Hemara-Wahanui A, Sissingh JI, Lundon P, Mitchell EA, Maw MA, Clover GM (2005) Clinical manifestations of a unique $\mathrm{X}$-linked retinal disorder in a large New Zealand family with a novel mutation in CACNA1F, the gene responsible for CSNB2. Clin Exp Ophthalmol 33:129-136. https://doi.org/ 10.1111/j.1442-9071.2005.00987.x

41. Hove MN, Kilic-Biyik KZ, Trotter A, Gronskov K, Sander B, Larsen M, Carroll J, Bech-Hansen T, Rosenberg T (2016) Clinical characteristics, mutation spectrum, and prevalence of Aland eye disease/incomplete congenital stationary night blindness in Denmark. Invest Ophthalmol Vis Sci 57:6861-6869. https://doi. org/10.1167/iovs.16-19445

42. Huang H, Yu D, Soong TW (2013) C-terminal alternative splicing of CaV1.3 channels distinctively modulates their dihydropyridine sensitivity. Mol Pharmacol 84:643-653. https://doi.org/ 10.1124/mol.113.087155

43. Huang XF, Huang F, Wu KC, Wu J, Chen J, Pang CP, Lu F, Qu J, Jin ZB (2015) Genotype-phenotype correlation and mutation spectrum in a large cohort of patients with inherited retinal dystrophy revealed by next-generation sequencing. Genet Med 17:271-278. https://doi.org/10.1038/gim.2014.138

44. Hulme JT, Konoki K, Lin TW, Gritsenko MA, Camp DG 2nd, Bigelow DJ, Catterall WA (2005) Sites of proteolytic processing and noncovalent association of the distal C-terminal domain of $\mathrm{Ca}_{\mathrm{v}} 1.1$ channels in skeletal muscle. Proc Natl Acad Sci U S A 102:5274-5279

45. Hulme JT, Yarov-Yarovoy V, Lin TW, Scheuer T, Catterall WA (2006) Autoinhibitory control of the $\mathrm{Ca}_{\mathrm{v}} 1.2$ channel by its proteolytically processed distal C-terminal domain. J Physiol

46. Jacobi FK, Hamel CP, Arnaud B, Blin N, Broghammer M, Jacobi PC, Apfelstedt-Sylla E, Pusch CM (2003) A novel CACNA1F mutation in a french family with the incomplete type of $\mathrm{X}$-linked congenital stationary night blindness. Am J Ophthalmol 135:733-736

47. Jalkanen R, Mantyjarvi M, Tobias R, Isosomppi J, Sankila EM, Alitalo T, Bech-Hansen NT (2006) X linked cone-rod dystrophy, 
CORDX3, is caused by a mutation in the CACNA1F gene. J Med Genet 43:699-704. https://doi.org/10.1136/jmg.2006.040741

48. Johnson JE Jr, Perkins GA, Giddabasappa A, Chaney S, Xiao W, White AD, Brown JM, Waggoner J, Ellisman MH, Fox DA (2007) Spatiotemporal regulation of ATP and $\mathrm{Ca} 2+$ dynamics in vertebrate rod and cone ribbon synapses. Mol Vis 13:887-919

49. Kerov V, Laird JG, Joiner ML, Knecht S, Soh D, Hagen J, Gardner SH, Gutierrez W, Yoshimatsu T, Bhattarai S, Puthussery T, Artemyev NO, Drack AV, Wong RO, Baker SA, Lee A (2018) alpha2delta-4 is required for the molecular and structural organization of rod and cone photoreceptor synapses. J Neurosci 38:6145-6160. https://doi.org/10.1523/JNEUROSCI.3818-16. 2018

50. Knoflach D, Kerov V, Sartori SB, Obermair GJ, Schmuckermair C, Liu X, Sothilingam V, Garcia Garrido M, Baker SA, Glosmann M, Schicker K, Seeliger M, Lee A, Koschak A (2013) Cav1.4 IT mouse as model for vision impairment in human congenital stationary night blindness type 2 . Channels (Austin) 7:503-513. https://doi.org/10.4161/chan.26368

51. Knoflach D, Schicker K, Glosmann M, Koschak A (2015) Gainof-function nature of Cav1.4 L-type calcium channels alters firing properties of mouse retinal ganglion cells. Channels (Austin) 9:298-306. https://doi.org/10.1080/19336950.2015.1078040

52. Koschak A, Reimer D, Huber I, Grabner M, Glossmann H, Engel J, Striessnig J (2001) a1D $\left(\mathrm{Ca}_{\mathrm{v}} 1.3\right)$ subunits can form L-type $\mathrm{Ca}^{2+}$ channels activating at negative voltages. J Biol Chem 276:22100-22106

53. Koschak A, Reimer D, Walter D, Hoda JC, Heinzle T, Grabner $\mathrm{M}$, Striessnig J (2003) $\mathrm{Ca}_{\mathrm{v}} 1.4 \mathrm{a} 1$ subunits can form slowly inactivating dihydropyridine-sensitive L-type $\mathrm{Ca}^{2+}$ channels lacking $\mathrm{Ca}^{2+}$-dependent inactivation. J Neurosci 23:6041-6049

54. Kourennyi DE, Liu XD, Hart J, Mahmud F, Baldridge WH, Barnes S (2004) Reciprocal modulation of calcium dynamics at rod and cone photoreceptor synapses by nitric oxide. J Neurophysiol 92:477-483. https://doi.org/10.1152/jn.00606.2003

55. Laird JG, Gardner SH, Kopel AJ, Kerov V, Lee A, Baker SA (2019) Rescue of Rod Synapses by Induction of Cav Alpha 1F in the Mature Cav1.4 Knock-Out Mouse Retina. Invest Ophthalmol Vis Sci 60:3150-3161. https://doi.org/10.1167/iovs.19-27226

56. Lee A, Wang S, Williams B, Hagen J, Scheetz TE, Haeseleer F (2015) Characterization of Cav1.4 complexes (alpha11.4, beta2, and alpha2delta4) in HEK293T cells and in the retina. J Biol Chem 290:1505-1521. https://doi.org/10.1074/jbc.M114.607465

57. Liu X, Yang PS, Yang W, Yue DT (2010) Enzyme-inhibitor-like tuning of $\mathrm{Ca}(2+)$ channel connectivity with calmodulin. Nature 463:968-972. https://doi.org/10.1038/nature08766

58. Liu X, Kerov V, Haeseleer F, Majumder A, Artemyev N, Baker SA, Lee A (2013) Dysregulation of Ca(v)1.4 channels disrupts the maturation of photoreceptor synaptic ribbons in congenital stationary night blindness type 2. Channels (Austin) 7:514-523. https://doi.org/10.4161/chan.26376

59. Liu N, Liu Y, Yang Y, Liu X (2017) Linker flexibility of IVS3-S4 loops modulates voltage-dependent activation of $\mathrm{L}$-type $\mathrm{Ca}(2+)$ channels. Channels (Austin) 11:34-45. https://doi.org/10.1080/ 19336950.2016.1207023

60. Lundstrom K (2018) Viral Vectors in Gene Therapy. Diseases 6. https://doi.org/10.3390/diseases6020042

61. Maddox JW, Randall KL, Yadav RP, Williams B, Hagen J, Derr PJ, Kerov V, Della Santina L, Baker SA, Artemyev N, Hoon M, Lee A (2020) A dual role for Cav1.4 $\mathrm{Ca}(2+)$ channels in the molecular and structural organization of the rod photoreceptor synapse. Elife 9. https://doi.org/10.7554/eLife.62184

62. Maguire AM, Russell S, Wellman JA, Chung DC, Yu ZF, Tillman A, Wittes J, Pappas J, Elci O, Marshall KA, McCague S, Reichert H, Davis M, Simonelli F, Leroy BP, Wright JF, High KA, Bennett J (2019) Efficacy, safety, and durability of voretigene neparvovec-rzyl in RPE65 mutation-associated inherited retinal dystrophy: results of phase 1 and 3 trials. Ophthalmology 126:1273-1285. https://doi.org/10.1016/j.ophtha.2019.06.017

63. Mansergh F, Orton NC, Vessey JP, Lalonde MR, Stell WK, Tremblay F, Barnes S, Rancourt DE, Bech-Hansen NT (2005) Mutation of the calcium channel gene Cacnalf disrupts calcium signaling, synaptic transmission and cellular organization in mouse retina. Hum Mol Genet 14:3035-3046. https://doi.org/ $10.1093 / \mathrm{hmg} / \mathrm{ddi} 336$

64. McRory JE, Hamid J, Doering CJ, Garcia E, Parker R, Hamming K, Chen L, Hildebrand M, Beedle AM, Feldcamp L, Zamponi GW, Snutch TP (2004) The CACNA1F gene encodes an L-type calcium channel with unique biophysical properties and tissue distribution. J Neurosci 24:1707-1718

65. Michalakis S, Shaltiel L, Sothilingam V, Koch S, Schludi V, Krause S, Zeitz C, Audo I, Lancelot ME, Hamel C, Meunier I, Preising MN, Friedburg C, Lorenz B, Zabouri N, Haverkamp S, Garcia Garrido M, Tanimoto N, Seeliger MW, Biel M, Wahl-Schott CA (2014) Mosaic synaptopathy and functional defects in Cav1.4 heterozygous mice and human carriers of CSNB2. Hum Mol Genet 23:1538-1550. https://doi.org/10. 1093/hmg/ddt541

66. Miyake Y (2002) Establishment of the concept of new clinical entities--complete and incomplete form of congenital stationary night blindness. Nippon Ganka Gakkai Zasshi 106:737-755 discussion 756

67. Nakamura M, Ito S, Terasaki H, Miyake Y (2001) Novel CACNA1F mutations in Japanese patients with incomplete congenital stationary night blindness. Invest Ophthalmol Vis Sci 42:1610-1616

68. Nakamura M, Ito S, Piao CH, Terasaki H, Miyake Y (2003) Retinal and optic disc atrophy associated with a CACNA1F mutation in a Japanese family. Arch Ophthalmol 121:1028-1033

69. Ortner NJ, Bock G, Dougalis A, Kharitonova M, Duda J, Hess S, Tuluc P, Pomberger T, Stefanova N, Pitterl F, Ciossek T, Oberacher H, Draheim HJ, Kloppenburg P, Liss B, Striessnig J (2017) Lower affinity of isradipine for L-type $\mathrm{Ca} 2+$ channels during substantia nigra dopamine neuron-like activity: implications for neuroprotection in Parkinson's disease. J Neurosci. https://doi. org/10.1523/JNEUROSCI.2946-16.2017

70. Pangrsic T, Singer JH, Koschak A (2018) Voltage-gated calcium channels: key players in sensory coding in the retina and the inner ear. Physiol Rev 98:2063-2096. https://doi.org/10.1152/ physrev.00030.2017

71. Papapetrou EP, Schambach A (2016) Gene insertion into genomic safe harbors for human gene therapy. Mol Ther 24:678684. https://doi.org/10.1038/mt.2016.38

72. Park S, Li C, Haeseleer F, Palczewski K, Ames JB (2014) Structural insights into activation of the retinal L-type $\mathrm{Ca}(2)$ (+) channel (Cav1.4) by $\mathrm{Ca}(2)$ (+)-binding protein 4 (CaBP4). J Biol Chem 289:31262-31273. https://doi.org/10.1074/jbc.M114. 604439

73. Pasutto F, Ekici A, Reis A, Kremers J, Huchzermeyer C (2018) Novel truncating mutation in CACNA1F in a young male patient diagnosed with optic atrophy. Ophthalmic Genet 39:741-748. https://doi.org/10.1080/13816810.2018.1520263

74. Peloquin JB, Doering CJ, Rehak R, McRory JE (2008) Temperature dependence of Cav1.4 calcium channel gating. Neuroscience 151:1066-1083. https://doi.org/10.1016/j.neuroscience.2007.11. 053

75. Petrs-Silva H, Yasumura D, Matthes MT, LaVail MM, Lewin AS, Hauswirth WW (2012) Suppression of rds expression by siRNA and gene replacement strategies for gene therapy using rAAV vector. Adv Exp Med Biol 723:215-223. https://doi.org/ 10.1007/978-1-4614-0631-0 29 
76. Pinggera A, Mackenroth L, Rump A, Schallner J, Beleggia F, Wollnik B, Striessnig J (2017) New gain-of-function mutation shows CACNA1D as recurrently mutated gene in autism spectrum disorders and epilepsy. Hum Mol Genet 26:2923-2932. https://doi.org/10.1093/hmg/ddx175

77. Raven MA, Orton NC, Nassar H, Williams GA, Stell WK, Jacobs GH, Bech-Hansen NT, Reese BE (2008) Early afferent signaling in the outer plexiform layer regulates development of horizontal cell morphology. J Comp Neurol 506:745-758. https://doi.org/ $10.1002 / \mathrm{cne} .21526$

78. Regus-Leidig H, Brandstatter JH (2012) Structure and function of a complex sensory synapse. Acta Physiol (Oxf) 204:479-486. https://doi.org/10.1111/j.1748-1716.2011.02355.x

79. Regus-Leidig H, Atorf J, Feigenspan A, Kremers J, Maw MA, Brandstatter JH (2014) Photoreceptor degeneration in two mouse models for congenital stationary night blindness type 2. PLoS ONE 9:e86769. https://doi.org/10.1371/journal.pone.0086769

80. Satoh H, Aoki K, Watanabe SI, Kaneko A (1998) L-type calcium channels in the axon terminal of mouse bipolar cells. Neuro Rep 9:2161-2165

81. Scharinger A, Eckrich S, Vandael DH, Schonig K, Koschak A, Hecker D, Kaur G, Lee A, Sah A, Bartsch D, Benedetti B, Lieb A, Schick B, Singewald N, Sinnegger-Brauns MJ, Carbone E, Engel J, Striessnig J (2015) Cell-type-specific tuning of $\mathrm{Cav} 1.3 \mathrm{Ca}(2+)$-channels by a C-terminal automodulatory domain. Front Cell Neurosci 9:309. https://doi.org/10.3389/ fncel.2015.00309

82. Shaltiel L, Paparizos C, Fenske S, Hassan S, Gruner C, Rotzer K, Biel M, Wahl-Schott CA (2012) Complex regulation of voltage-dependent activation and inactivation properties of retinal voltage-gated Cav1.4 L-type $\mathrm{Ca} 2+$ channels by $\mathrm{Ca} 2+-$-binding protein 4 (CaBP4). J Biol Chem 287:36312-36321. https://doi. org/10.1074/jbc.M112.392811

83. Simonsz HJ, Florijn RJ, van Minderhout HM, Bergen AA, Kamermans M (2009) Nightblindness-associated transient tonic downgaze (NATTD) in infant boys with chin-up head posture. Strabismus 17:158-164. https://doi.org/10.3109/0927397090 3396893

84. Singh A, Hamedinger D, Hoda JC, Gebhart M, Koschak A, Romanin C, Striessnig J (2006) C-terminal modulator controls $\mathrm{Ca}^{2+}$-dependent gating of $\mathrm{Ca}_{\mathrm{v}} 1.4 \mathrm{~L}$-type $\mathrm{Ca}^{2+}$ channels. Nat Neurosci 9:1108-1116. https://doi.org/10.1038/nn1751

85. Singh A, Gebhart M, Fritsch R, Sinnegger-Brauns MJ, Poggiani C, Hoda JC, Engel J, Romanin C, Striessnig J, Koschak A (2008) Modulation of voltage- and Ca2+-dependent gating of CaV1.3 L-type calcium channels by alternative splicing of a C-terminal regulatory domain. J Biol Chem. https://doi.org/10.1074/jbc. M802254200

86. Specht D, Wu SB, Turner P, Dearden P, Koentgen F, Wolfrum U, Maw M, Brandstatter JH, tom Dieck S, (2009) Effects of presynaptic mutations on a postsynaptic Cacna1s calcium channel colocalized with mGluR6 at mouse photoreceptor ribbon synapses. Invest Ophthalmol Vis Sci 50:505-515. https://doi.org/10.1167/ iovs.08-2758

87. Splawski I, Timothy KW, Sharpe LM, Decher N, Kumar P, Bloise R, Napolitano C, Schwartz PJ, Joseph RM, Condouris K, Tager-Flusberg H, Priori SG, Sanguinetti MC, Keating MT (2004) $\mathrm{Ca}(\mathrm{V}) 1.2$ calcium channel dysfunction causes a multisystem disorder including arrhythmia and autism. Cell 119:19-31. https://doi.org/10.1016/j.cell.2004.09.011

88. Stella SL Jr, Thoreson WB (2000) Differential modulation of rod and cone calcium currents in tiger salamander retina by D2 dopamine receptors and cAMP. Eur J Neurosci 12:3537-3548. https://doi.org/10.1046/j.1460-9568.2000.00235.x

89. Stockner T, Koschak A (2013) What can naturally occurring mutations tell us about $\mathrm{Ca}(\mathrm{v}) 1 . \mathrm{x}$ channel function? Biochim
Biophys Acta 1828:1598-1607. https://doi.org/10.1016/j. bbamem.2012.11.026

90. Strom TM, Nyakatura G, Apfelstedt-Sylla E, Hellebrand H, Lorenz B, Weber BH, Wutz K, Gutwillinger N, Ruther K, Drescher B, Sauer C, Zrenner E, Meitinger T, Rosenthal A, Meindl A (1998) An L-type calcium-channel gene mutated in incomplete X-linked congenital stationary night blindness. Nat Genet 19:260-263. https://doi.org/10.1038/940

91. Subramanyam P, Chang DD, Fang K, Xie W, Marks AR, Colecraft HM (2013) Manipulating L-type calcium channels in cardiomyocytes using split-intein protein transsplicing. Proc Natl Acad Sci U S A 110:15461-15466. https://doi.org/10.1073/pnas. 1308161110

92. Suzuki K, Tsunekawa Y, Hernandez-Benitez R, Wu J, Zhu J, Kim EJ, Hatanaka F, Yamamoto M, Araoka T, Li Z, Kurita M, Hishida T, Li M, Aizawa E, Guo S, Chen S, Goebl A, Soligalla RD, Qu J, Jiang T, Fu X, Jafari M, Esteban CR, Berggren WT, Lajara J, Nunez-Delicado E, Guillen P, Campistol JM, Matsuzaki F, Liu GH, Magistretti P, Zhang K, Callaway EM, Zhang K, Belmonte JC (2016) In vivo genome editing via CRISPR/Cas9 mediated homology-independent targeted integration. Nature 540:144-149. https://doi.org/10.1038/nature20565

93. Tajima S, Shinohara K, Fukumoto M, Zaitsu R, Miyagawa J, Hino S, Fan J, Akasaka K, Matsuoka M (2006) Ars insulator identified in sea urchin possesses an activity to ensure the transgene expression in mouse cells. J Biochem 139:705-714. https://doi.org/10.1093/jb/mvj075

94. Tam LC, Kiang AS, Kennan A, Kenna PF, Chadderton N, Ader M, Palfi A, Aherne A, Ayuso C, Campbell M, Reynolds A, McKee A, Humphries MM, Farrar GJ, Humphries P (2008) Therapeutic benefit derived from RNAi-mediated ablation of IMPDH1 transcripts in a murine model of autosomal dominant retinitis pigmentosa (RP10). Hum Mol Genet 17:2084-2100. https://doi.org/10.1093/hmg/ddn107

95. Tan GM, Yu D, Wang J, Soong TW (2012) Alternative splicing at $\mathrm{C}$ terminus of $\mathrm{Ca}(\mathrm{V}) 1.4$ calcium channel modulates calciumdependent inactivation, activation potential, and current density. J Biol Chem 287:832-847. https://doi.org/10.1074/jbc.M111. 268722

96. Tanimoto N, Sothilingam V, Kondo M, Biel M, Humphries P, Seeliger MW (2015) Electroretinographic assessment of rodand cone-mediated bipolar cell pathways using flicker stimuli in mice. Sci Rep 5:10731. https://doi.org/10.1038/srep10731

97. Tornabene P, Trapani I, Minopoli R, Centrulo M, Lupo M, de Simone S, Tiberi P, Dell'Aquila F, Marrocco E, Iodice C, Iuliano A, Gesualdo C, Rossi S, Giaquinto L, Albert S, Hoyng CB, Polishchuk E, Cremers FPM, Surace EM, Simonelli F, De Matteis MA, Polishchuk R, Auricchio A (2019) Intein-mediated protein trans-splicing expands adeno-associated virus transfer capacity in the retina. Sci Transl Med 11. https://doi.org/10.1126/scitranslm ed.aav4523

98. Trapani I, Colella P, Sommella A, Iodice C, Cesi G, de Simone S, Marrocco E, Rossi S, Giunti M, Palfi A, Farrar GJ, Polishchuk R, Auricchio A (2014) Effective delivery of large genes to the retina by dual AAV vectors. EMBO Mol Med 6:194-211. https:// doi.org/10.1002/emmm.201302948

99. Urnov FD, Rebar EJ, Holmes MC, Zhang HS, Gregory PD (2010) Genome editing with engineered zinc finger nucleases. Nat Rev Genet 11:636-646. https://doi.org/10.1038/nrg2842

100. Vincent A, Wright T, Day MA, Westall CA, Heon E (2011) A novel p.Gly603Arg mutation in CACNA1F causes Aland island eye disease and incomplete congenital stationary night blindness phenotypes in a family. Mol Vis 17:3262-3270

101. von Gersdorff H, Matthews G (1996) Calcium-dependent inactivation of calcium current in synaptic terminals of retinal bipolar neurons. J Neurosci 16:115-122 
102. Wahl-Schott C, Baumann L, Cuny H, Eckert C, Griessmeier K, Biel M (2006) Switching off calcium-dependent inactivation in L-type calcium channels by an autoinhibitory domain. Proc Natl Acad Sci U S A 103:15657-15662. https://doi.org/10.1073/pnas. 0604621103

103. Waldner DM, Giraldo Sierra NC, Bonfield S, Nguyen L, Dimopoulos IS, Sauve Y, Stell WK, Bech-Hansen NT (2018) Cone dystrophy and ectopic synaptogenesis in a Cacnalf loss of function model of congenital stationary night blindness (CSNB2A). Channels (Austin) 12:17-33. https://doi.org/10.1080/19336950. 2017.1401688

104. Waldner DM, Ito K, Chen LL, Nguyen L, Chow RL, Lee A, Rancourt DE, Tremblay F, Stell WK, Bech-Hansen NT (2020) Transgenic expression of cacnalf rescues vision and retinal morphology in a mouse model of congenital stationary night blindness 2A (CSNB2A). Transl Vis Sci Technol 9:19. https://doi.org/ 10.1167/tvst.9.11.19

105. Wang Y, Fehlhaber KE, Sarria I, Cao Y, Ingram NT, GuerreroGiven D, Throesch B, Baldwin K, Kamasawa N, Ohtsuka T, Sampath AP, Martemyanov KA (2017) The auxiliary calcium channel Subunit alpha2delta4 is required for axonal elaboration, synaptic transmission, and wiring of rod photoreceptors. Neuron 93(1359-1374):e1356. https://doi.org/10.1016/j.neuron.2017.02. 021

106. Weleber RG (2002) Infantile and childhood retinal blindness: a molecular perspective (The Franceschetti Lecture). Ophthalmic Genet 23:71-97. https://doi.org/10.1076/opge.23.2.71.2214

107. Wilkinson MF, Barnes S (1996) The dihydropyridine-sensitive calcium channel subtype in cone photoreceptors. J Gen Physiol 107:621-630

108. Williams B, Haeseleer F, Lee A (2018) Splicing of an automodulatory domain in $\mathrm{Cav} 1.4 \mathrm{Ca}(2+)$ channels confers distinct regulation by calmodulin. J Gen Physiol 150:1676-1687. https://doi. org/10.1085/jgp.201812140

109. Williams B, Lopez JA, Maddox JW, Lee A (2020) Functional impact of a congenital stationary night blindness type 2 mutation depends on subunit composition of Cav1.4 $\mathrm{Ca}(2+)$ channels. J Biol Chem. https://doi.org/10.1074/jbc.RA120.014138

110. Witkovsky P, Schmitz Y, Akopian A, Krizaj D, Tranchina D (1997) Gain of rod to horizontal cell synaptic transfer: relation to glutamate release and a dihydropyridine-sensitive calcium current. J Neurosci 17:7297-7306

111. Wright DA, Li T, Yang B, Spalding MH (2014) TALEN-mediated genome editing: prospects and perspectives. Biochem $\mathrm{J}$ 462:15-24. https://doi.org/10.1042/BJ20140295

112. Wu Z, Yang H, Colosi P (2010) Effect of genome size on AAV vector packaging. Mol Ther 18:80-86. https://doi.org/10.1038/ mt.2009.255

113. Wu J, Yan Z, Li Z, Qian X, Lu S, Dong M, Zhou Q, Yan N (2016) Structure of the voltage-gated calcium channel $\mathrm{Ca}(\mathrm{v}) 1.1$ at 3.6 A resolution. Nature 537:191-196. https://doi.org/10.1038/natur e19321

114. Wutz K, Sauer C, Zrenner E, Lorenz B, Alitalo T, Broghammer M, Hergersberg M, Chapelle Ade L, Weber BH, Wissinger B, Meindl A, Pusch CM (2002) Thirty distinct CACNA1F mutations in 33 families with incomplete type of XLCSNB and Cacnalf expression profiling in mouse retina. Eur J Hum Genet $10: 449-456$
115. Wycisk KA, Zeitz C, Feil S, Wittmer M, Forster U, Neidhardt J, Wissinger B, Zrenner E, Wilke R, Kohl S, Berger W (2006) Mutation in the auxiliary calcium-channel subunit CACNA2D4 causes autosomal recessive cone dystrophy. Am J Hum Genet 79:973-977. https://doi.org/10.1086/508944

116. Xu W, Lipscombe D (2001) Neuronal $\mathrm{Ca}_{\mathrm{v}} 1.3 \mathrm{a} 1$ L-type channels activate at relatively hyperpolarized membrane potentials and are incompletely inhibited by dihydropyridines. J Neurosci 21:5944-5951

117. Xu H, Zhao J, Yang X (2002) Expression of voltage-dependent calcium channel subunits in the rat retina. Neurosci Lett 329:297

118. Zabouri N, Haverkamp S (2013) Calcium channel-dependent molecular maturation of photoreceptor synapses. PLoS ONE 8:e63853. https://doi.org/10.1371/journal.pone.0063853

119. Zamponi GW, Striessnig J, Koschak A, Dolphin AC (2015) The physiology, pathology, and pharmacology of voltage-gated calcium channels and their future therapeutic potential. Pharmacol Rev 67:821-870. https://doi.org/10.1124/pr.114.009654

120. Zanetti L, Kilicarslan I, Netzer M, Babai N, Seitter H, Koschak A (2021) Function of cone and cone-related pathways in CaV1.4 IT mice. Sci Rep 11:2732. https://doi.org/10.1038/ s41598-021-82210-7

121. Zeitz C, Minotti R, Feil S, Matyas G, Cremers FP, Hoyng CB, Berger W (2005) Novel mutations in CACNA1F and NYX in Dutch families with $\mathrm{X}$-linked congenital stationary night blindness. Mol Vis 11:179-183

122. Zeitz C, Kloeckener-Gruissem B, Forster U, Kohl S, Magyar I, Wissinger B, Matyas G, Borruat FX, Schorderet DF, Zrenner E, Munier FL, Berger W (2006) Mutations in CABP4, the gene encoding the $\mathrm{Ca} 2+$-binding protein 4 , cause autosomal recessive night blindness. Am J Hum Genet 79:657-667

123. Zeitz C, Labs S, Lorenz B, Forster U, Uksti J, Kroes HY, De Baere E, Leroy BP, Cremers FP, Wittmer M, van Genderen MM, Sahel JA, Audo I, Poloschek CM, Mohand-Said S, Fleischhauer JC, Huffmeier U, Moskova-Doumanova V, Levin AV, Hamel CP, Leifert D, Munier FL, Schorderet DF, Zrenner E, Friedburg C, Wissinger B, Kohl S, Berger W (2009) Genotyping microarray for CSNB-associated genes. Invest Ophthalmol Vis Sci 50:5919 5926. https://doi.org/10.1167/iovs.09-3548

124. Zeitz C, Robson AG, Audo I (2015) Congenital stationary night blindness: an analysis and update of genotype-phenotype correlations and pathogenic mechanisms. Prog Retin Eye Res 45:58110. https://doi.org/10.1016/j.preteyeres.2014.09.001

125. Zhou Q, Cheng J, Yang W, Tania M, Wang H, Khan MA, Duan C, Zhu L, Chen R, Lv H, Fu J (2015) Identification of a novel heterozygous missense mutation in the CACNA1F gene in a chinese family with retinitis pigmentosa by next generation sequencing. Biomed Res Int 2015:907827. https://doi.org/10.1155/2015/ 907827

126. Zito I, Allen LE, Patel RJ, Meindl A, Bradshaw K, Yates JR, Bird AC, Erskine L, Cheetham ME, Webster AR, Poopalasundaram S, Moore AT, Trump D, Hardcastle AJ (2003) Mutations in the CACNA1F and NYX genes in British CSNBX families. Hum Mutat 21:169. https://doi.org/10.1002/humu.9106

Publisher's note Springer Nature remains neutral with regard to jurisdictional claims in published maps and institutional affiliations. 